\title{
The religious landscape of North-west Arabia as reflected in the Nabataean, Nabataeo-Arabic, and pre-Islamic Arabic inscriptions
}

\author{
Laïla Nehmé, CNRS, Orient \& Méditerranée
}

\begin{abstract}
This article examines the divine figures attested in the Nabataean, Nabataeo-Arabic and preIslamic Arabic inscriptions from the Arabian peninsula from the first to the 6th century AD. The list of the divine figures attested in these texts, either mentioned as such or contained in theophoric names, is based on the examination of all the corpuses, published or unpublished, which are available to the author (from Madā'in Șāliḥ, Taymā’ and its region, Dūmat al-Jandal, etc.). The identification of about 400 divine names in the inscriptions allows to draw a picture of the deities who appear in different places at different times. Among the main conclusions are the identification of regional variations within the Nabataean kingdom and a decrease of the number of divine figures in the Nabataeo-Arabic and pre-Islamic Arabic inscriptions, in favour of figures such as $m r y$ ' $l m^{\prime}$ and ' $l$ 'lh (masculine) and ' $l t$, ' $l{ }^{\prime} z$ ' and $m n w t w$ (feminine).
\end{abstract}

This contribution comes from a paper I originally gave at the University of Chicago in 2017, during the conference organized by Fred Donner entitled "Scripts and Scripture: Language and Religion in Arabia, circa 500-700". ${ }^{1}$

The initial aim of my paper was to examine whether the gods mentioned in the Nabataean inscriptions from the Arabian peninsula were the same as those mentioned in the NabataeoArabic and pre-Islamic Arabic texts from the same region. The objective was thus to determine what sort of evolution in the religious landscape can be traced between the first and the sixth century $\mathrm{AD}$ on the basis of a particular corpus of inscriptions. However, while I was collecting the material in the various corpora which needed to be taken into account, I realized that the gods who appear in the Nabataean inscriptions from the Arabian peninsula (as opposed to those from other regions of the Nabataean kingdom: Petra, the Hawrān, the Negev, Sinai, etc.) showed specificities which were also worth pointing out, e.g. the mention of local gods who do not appear elsewhere, or the popularity of certain gods over others.

Of course, the Arabian peninsula was never all part of the Nabataean kingdom. Therefore, when one deals with the Nabataean inscriptions recorded in this vast geographical area, one refers to regions which were either part of the Nabataean kingdom (at least down to Hegra, modern Madā' in Șālih/al-Hijr), were in the Nabataean area of influence (probably down to Yathrib, modern Medina), or were regions where a Nabataean presence is attested (down to South Arabia and the Farasān islands).

The three categories of script mentioned in the title of this contribution can be defined schematically as follows: the Nabataean inscriptions are written in a 'calligraphic' or 'classical' form of the Nabataean script, where most of the letters would be at home in Petra in the first century AD. They may show regional particularities but the letters are all recognizably

\footnotetext{
${ }^{1}$ I am very grateful to Fred Donner for inviting me to this very enriching conference and for giving me the opportunity to visit our colleagues at the Oriental Institute. I also thank Michael Macdonald for reading an earlier draft of this paper. Any remaining mistakes are of course mine.
} 
Nabataean and do not show clear traces of evolution. Nabataeo-Arabic inscriptions are written in a script the letters of which are starting to change, i.e. they are transitional between Nabataean and Arabic. The script is however not homogenous, some letters being evolved and others not. Finally, the pre-Islamic Arabic inscriptions are written in a recognizable form of Arabic. They represent the outcome of the evolution and the letters are more standardized. On the basis of all the dated texts that are available so far, these categories can be chronologically defined as follows:

- Nabataean: first century BC to mid-third century AD;

- Nabataeo-Arabic: late-third to mid-fifth century AD;

- pre-Islamic Arabic: late fifth and sixth centuries AD.

One should keep in mind that the distinction between these three categories of scripts is sometimes difficult to make. One is dealing with short texts which do not always contain diagnostic letter forms, which do not clearly belong to one category or the other, or which contain both 'developed' and 'archaic' letter forms. The linguistic status of the inscriptions written in these scripts is another issue which is difficult to address. The Nabataean inscriptions are generally written in Aramaic but they contain a number of Arabic loanwords. It should be remembered that, if one excepts the Nabataean papyri from the Dead Sea region, ${ }^{2}$ North-west Arabia is the region which has yielded by far the largest number of Arabic loanwords in the Nabataean inscriptions. It has also been reasonably argued ${ }^{3}$ that the Nabataeans spoke Arabic, but it is difficult to be certain whether this was uniformly the case at all times and in all the regions under control by the Nabataeans. As for the Nabataeo-Arabic and even the pre-Islamic Arabic texts, the question of their language is complicated by the following facts: ${ }^{4} 1 /$ they contain a very limited number of words (as opposed to personal names); 2 / even when they do contain words, these often belong to radicals which can be either Aramaic or Arabic (e.g. ktb, $y d$, šnt, etc.) and therefore cannot be used as criteria to determine the language of the texts in which they are used (unless they appear in derived forms which are either clearly Aramaic or clearly Arabic); 3/ even some of the pre-Islamic Arabic texts contain Aramaic words sometimes used as fossils (e.g. br, "son of", see Macdonald 2010: 20).

This being considered, my wish was to collect, in all the possible corpora of inscriptions which were at my disposal, anything which could be identified either as a divine name or as a theophoric name. Obviously, these two groups do not have the same value: deities whose names appear in funerary and religious texts, or even in simple signatures carved by individuals on the rocks, were certainly the object of some sort of worship, in whatever form. They can therefore be considered as direct evidence. Conversely, theophoric names are at best indirect evidence for the worship of the deities who are mentioned in them. Indeed, as has been amply demonstrated by Macdonald (1999), personal names neither reflect the ethnic affiliation of the

\footnotetext{
2 In 2014, A. Yardeni published an article in which she gives a list of the words she identified as Arabic in the Nabataean and Aramaic legal documents from the Judaean Desert. This list contains fifty-nine items, for each of which a translation is proposed and citations of the phrases in which each word appears is provided.

3 Most recently in Macdonald 2010: 19-21.

${ }^{4}$ On the language issue, see among others Nehmé 2017a and Robin et al. 2014.
} 
bearer's parents nor their religious beliefs. They should therefore not be used to describe the cultic preferences of those who bore them. These reservations kept in mind, it seemed however reasonable to assume, as a working hypothesis, that theophoric names do reflect, to a certain extent, the religious landscape of the regions and at the periods in which they appear, if and only if one appeals to the statistical value of series of names taken from as large a number of inscriptions as possible.

\section{Methodology, documentary aspects}

The first step of my research was to collect the material, i.e. the divine names and theophoric personal names attested in the inscriptions written in the three categories of scripts distinguished above. Since I needed to collect as representative a body of material as possible, I decided to take into account all the inscriptions the existence of which I was aware. These belong to three kinds of documentary sources:

A. Published material. This includes the various collections of inscriptions from the Arabian peninsula, usefully assembled by Sulaymān al-Dhuyayb in the two volumes of his Mudawwanat al-nuqūš al-nabatiyyah (al-Theeb 2010). The Mudawwanat contains 967 inscriptions, only $1 \%$ of which had not been published previously. Note that a few published inscriptions are missing from the Mudawwanat. ${ }^{5}$ To these have been added the inscriptions recorded in works published after the closing date of the Mudawwanat (al-Theeb 2011a, 2011b, 2014, al-Hā̄ițī 2016, Robin et al. 2014, etc.), as well as the inscriptions discovered along the so-called Darb al-Bakrah, which is the name given to the ancient itinerary between Madâ' in Șālih and the Jordanian border (912 texts, c. 500 of which were not previously published). ${ }^{6}$ If we add to these inscriptions those which are either under publication process or were discovered recently during survey projects which are sometimes still ongoing (for which see hereafter), the total number of Nabataean, Nabataeo-Arabic and pre-Islamic Arabic inscriptions from the Arabian peninsula reaches about 2,000 texts.

B. Texts in the process of publication. These include:

- the inscriptions carved either in the Jabal Ithlib area, north-east of Madā’in Șālih (ancient Hegra), or associated with religious monuments in other areas of the same site ${ }^{7}$ (c. 200 texts). These texts are being prepared for publication by the author;

- the inscriptions from the Taymä Museum which are soon to be published by Michael Macdonald and Muhammad al-Najem (5 texts);

- the inscriptions from the Taymä ${ }^{3}$ excavations, which are soon to be published by Michael Macdonald (10 texts in the Nabataean script) ${ }^{9}$.

\footnotetext{
${ }^{5}$ For instance, unless I am mistaken: ARNA.Nab 15, CIS II 308, 321-323, 326-335, 338-339, 340-345, 346348, the inscriptions published in Eskoubi 1999 and 2007, those mentioned in Livingstone et al. $1985: 142$ and finally those in Moritz 1908.

6 al-Ghabbān 2007, now all published in Nehmé 2018.

${ }^{7}$ For the publication of some of them, see Nehmé 2005-2006.

${ }^{8}$ I am very grateful to Michael Macdonald who kindly gave me access to the material from the Taymā' excavations and museum and allowed me to mention the divine and theophoric names they contain.

${ }^{9}$ There are also six texts in the Taymä' Aramaic script but they have not been included in this study, except one which is dated to the reign of a Nabataean king, TA 14285 + TA 14286.
} 
- the inscriptions photographed in the regions of Sakākā and al-Jawf (ancient Dūmah) during the surveys undertaken by the Dūmat al-Jandal Archaeological Project (under the direction of G. Charloux) between 2009 and 2017. The examination of the $c .300$ photographs taken by the team members showing Nabataean inscriptions allowed for the identification of 68 previously unpublished texts. These texts are also being prepared for publication by the author; ${ }^{10}$

- the inscriptions photographed in the region of Taymä' in 2013 and 2015 during two seasons of the Taymā' Epigraphic Survey Project (directed by M.C.A. Macdonald). The examination of more than 5,000 photographs allowed for the identification of c. 30 previously unpublished texts; ${ }^{11}$

- the inscriptions photographed in the region of Najrān during the surveys undertaken between 2007 and 2017 by the Saudi-French Najrān Archaeological Project (led by Chr. Robin). To my knowledge, four previously unpublished Nabataean inscriptions were photographed. The twenty-five Nabataeo-Arabic and pre-Islamic Arabic inscriptions from the Himā area, $100 \mathrm{~km}$ north of Najrān, discovered in 2014, have been published in Robin et al. in 2014.

- the inscriptions copied in various locations by H.St.J.B. Philby and R.E. Bogue during their expedition to Saudi Arabia in 1953.12

Up to 2017, 165 sites with inscriptions have been identified in the Arabian peninsula, a figure which increases year after year thanks to the new surveys undertaken. It does not, however, increase exponentially, particularly in the area south of ancient Hegra, where the Nabataean inscriptions remain a rarity. All the new inscriptions from the collections mentioned above were read, at least in a preliminary way, in order to collect the divine and theophoric names they contain. As for the previously known inscriptions, the names they contain were, whenever possible, checked on the original photographs. In total, 393 records of either divine or theophoric names were entered in a Filemaker database which thus contains the most complete and up to date corpus of this category of material.

\section{General remarks on the corpus}

One should keep in mind that the number of records in the database might change slightly in the future if some names are removed and others added. Besides, new inscriptions are discovered every day, and the field is in constant evolution. The figures which are given today will therefore soon be outdated, but they nevertheless give an idea of the available data and of the distribution of the names according to various criteria. For example, 65 records are divine names or divine epithets while 314 are theophoric personal names. Note that by "divine epithet"

\footnotetext{
${ }^{10}$ A first group of eighteen texts from one site near Dūmah has already been published, see Nehmé 2017b.

${ }^{11} \mathrm{I}$ am again very grateful to M.C.A. Macdonald for letting me go through the material of the Taymä Epigraphic Survey.

12 The Nabataean texts have been handed over to E. Littmann and, after his death, to J. Starcky so that he could include them in the new volume of CIS II. Starcky died in 1987 but the Nabataean material was already in J.T. Milik's hands, who passed over the manuscript to me before he died in 2006. I was therefore able to see that Milik had given new $C I S$ numbers to the Nabataean inscriptions copied by Philby and Bogue. The copies made by Philby and Bogue were sent to me by M.C.A. Macdonald who had received them from J. Ryckmans in 1993.
} 
I mean a deity who is not mentioned by his/her name but by a periphrasis such as 'lh $g y^{\prime}$ (sometimes spelled 'lh gy"), "the god of Gaia".

If we consider the category of script in which the inscriptions are written, we can say that 350 divine or theophoric names are contained in inscriptions written in the Nabataean script, 24 are contained in inscriptions written in the Nabataeo-Arabic script and 8 are contained in inscriptions written in pre-Islamic Arabic. The overwhelming majority of the recorded items thus appear in the Nabataean inscriptions, which is not surprising. Finally, as far as the geographical distribution is concerned, almost all the names, whether divine or theophoric, come from North-west Arabia, and only five come from inscriptions discovered in the southern part of the Arabian peninsula. This reflects of course the distribution of the Nabataean inscriptions themselves, the overwhelming majority of which come from an area which stretches from Aqaba to Sakākā and down to Khaybar in the south.

\section{The divine names or epithets attested in the Arabian peninsula}

In the tables presented below, the inscriptions bear the numbers which have been given to them in the relevant projects, e.g. DaJ = Dūmat al-Jandal, MS = Madā’in Șāliḥ, etc. (see the list of sigla). They have not been renumbered because they belong to different corpora which will be published separately. The inscription numbers which are followed by a hash (\#) are presented in the appendix at the end of this paper. This appendix has been added for the convenience of the reader and gives, in alphabetical order of the siglum, a selection of both published and unpublished texts. When a text is recorded in S. al-Theeb's Mudawwanat (ThMNN), this number is used preferentially but is usually followed by the better known JSNab or CIS number. A concordance of the references used in the table will help the reader find his way in the numbering of the inscriptions.

\subsection{Names or epithets attested in Nabataean only}

\begin{tabular}{|c|c|c|}
\hline $\begin{array}{l}\text { Name or } \\
\text { expression }\end{array}$ & No. of attest. & Comment \\
\hline 'lh $g y^{\prime}$ & $4 \mathrm{x}$ & $\begin{array}{l}\text { In three inscriptions from Umm Jadhāyidh, } \\
\text { ThMNN 477\#, } 688 \text { and UJadhNab 402, and in one } \\
\text { from Dūmah (Savignac and Starcky 1957). }\end{array}$ \\
\hline 'lhy' klhm & $3 x$ & $\begin{array}{l}\text { This expression, which means "all the gods", was } \\
\text { taken into account because it refers to the worship } \\
\text { of a number of gods. It occurs in ThMNN } \\
200,555 \text {, and } 681 \text {. }\end{array}$ \\
\hline${ }^{\prime} l^{c} z^{\prime}$ & $1 \mathrm{x}$ & $\begin{array}{l}\text { MS8Nab1\# (Nehmé 2005-2006: no. 12, p. 189- } \\
\text { 194, fig. 134). }\end{array}$ \\
\hline 'lt & $6 x$ & $\begin{array}{l}\text { ThMNN 205, 306, 307, and 662, plus two } \\
\text { unpublished inscriptions from the site of Qiyāl, } \\
\text { northwest of Sakākā, DaJ29Nab13\# and } \\
\text { DaJ29Nab24\#. }\end{array}$ \\
\hline "r'dy bbșr' 'lh rb'l & $1 \mathrm{x}$ & $\begin{array}{l}\text { ThMNN } 1 \text { (JSNab 39, Madā'in Șālih). This very } \\
\text { interesting text (on which see Nehmé } 2009: 43- \\
\text { 44) was probably written by someone who came } \\
\text { from Boșrā in southern Syria, hence the mention } \\
\text { of ' } r \text { ', probably meant to be } d w \check{s}^{\prime} r \text { ' ' } r \text { '. }\end{array}$ \\
\hline$\left.r^{\prime}\left({ }^{\prime}\right] r^{\prime} ?\right)$ & $1 x$ & $\begin{array}{l}\text { JSNab } 201 \text { (Mabrak an-Nāqah). There is no copy } \\
\text { of this text which was read ... } q d m^{\prime} r \text { ' (for } q d m\end{array}$ \\
\hline
\end{tabular}




\begin{tabular}{|c|c|c|}
\hline & & $\begin{array}{l}\text { "r?") ---- mnwtw btb. For ' } r \text { ', see the previous } \\
\text { line. }\end{array}$ \\
\hline$d w \check{s} r^{\prime}$ & $21 x$ & $\begin{array}{l}\text { From a variey of sites: Nebes 2009, ThMNN 14, } \\
\text { 107\#, 133, 190, 197, 200, 205, 209, 218, 220, 221, } \\
226,278,688,692,705,819 ; \text { UJadhNab 226, 391, } \\
402 .\end{array}$ \\
\hline$h b l$ & $1 \mathrm{x}$ & $\begin{array}{l}\text { ThMNN } 205 \text { (JSNab 16, Madā'in Sāalih), in the } \\
\text { cursing formula of the legal text carved on a tomb, } \\
\text { along with } d w s ̌ r \\
\text { '. }\end{array}$ \\
\hline$m[n] w t$ & $1 \mathrm{x}$ & $\begin{array}{l}\text { In UJadhNab } 391 \text {, the author wrote } m w t \text {, which is } \\
\text { probably a mistake for } m n w t \text { ( } m n q d m d w \check{s} r^{\prime} w \\
m[n] w t) \text {. }\end{array}$ \\
\hline mnwtw & $7 x$ & $\begin{array}{l}\text { All from previously published texts: ThMNN 197, } \\
205,209,221,224,295,705 \text {. }\end{array}$ \\
\hline mntw & $3 \mathrm{x}$ & $\begin{array}{l}\text { All from previously published texts: ThMNN 278, } \\
292,549 \text {. }\end{array}$ \\
\hline$m r$ byt $t^{\prime} / m r^{\prime} b y t^{\prime}$ & $4 \mathrm{x}$ & $\begin{array}{l}\text { All from Madā'in Șālih and all from previously } \\
\text { published texts: MS8Nab1\#; ThMNN 19, 20, } 21 .\end{array}$ \\
\hline qyšh and byt qyšs & $2 x$ and $1 x$ & $\begin{array}{l}\text { All from Madā'in Sāliḥ: ThMNN 197, 205, } 226 . \\
\text { This is either a deity or a divine attribute. }\end{array}$ \\
\hline$\{r\} s w$ & $1 \mathrm{x}$ & $\begin{array}{l}\text { Unpublished text from the site of Qiyāl, c. } 15 \mathrm{~km} \\
\text { north-west of Sakākā, DaJ29Nab1\#. This is to my } \\
\text { knowledge the only attestation of Rudia in the } \\
\text { Nabataean inscriptions. }\end{array}$ \\
\hline šmy & $2 \mathrm{x}$ & $\begin{array}{l}\text { CIS II 236\# and a text discovered at Madā' in Șālih } \\
\text { in 2016,64114_I01\#. }\end{array}$ \\
\hline$t b w \check{s}$ & $1 \mathrm{x}$ & $\begin{array}{l}\text { This deity, if the reading is correct, is attested in } \\
\text { one text only, ThMNN 107\# (JSNab 142), from } \\
\text { Madā'in Șālih. }\end{array}$ \\
\hline tdh/trh & $1 \mathrm{x}$ & $\begin{array}{l}\text { ThMNN 166\# (CIS II 336, from Taymä } \bar{a}^{\prime} \text {. Female } \\
\text { deity not attested elswhere. Michael Macdonald } \\
\text { suggests however that this text is written in the } \\
\text { Tayma } \bar{a}^{\prime} \text { Aramaic script (pers. comm.). }\end{array}$ \\
\hline tdhy/trhy & $1 x$ & $\begin{array}{l}\text { Legal text from Madā'in Sālih, ThMNN } 201 \\
\text { (JSNab 12), where the fine should be paid to } \\
\text { tdhy/trhy. Since the owners of the tomb are } \\
\text { Taymanites, it is likely that } t d h y / t r h y \text { and } t d h / t r h \\
\text { in the previous line are the same female deity. }\end{array}$ \\
\hline
\end{tabular}

Two periphrases are used to designate deities, $m r b y t^{\prime}$ (or $m r^{\prime} b y t^{\prime}$ ) and ' $l h g y^{\prime}$. The first one, which means "The Lord of the house" or "The Lord of the temple", behind which probably lies a major divine figure such as Dūšarā, appears four times, all from Hegra. Elsewhere in the Nabataean kingdom, it occurs once in Petra, once in Wadi Ramm and once in Zīza near Madaba, all in Jordan (see Nehmé 2005-2006: 192). It is therefore attested several times in the heart of the Nabataean kingdom and it is not surprising to find it in Hegra. The same is true of 'lh gy', "the god of Gaia". We find this periphrasis in Avdat in the Negev, where it refers explicitly to Dūšarā (Negev 1963: no. 10, p. 113), and in al-'Adnāniyyah on the Moab plateau, without any specification of the god (al-Salameen and Shdaifat 2017). In an inscription from Wādī Ram, ${ }^{13}$

13 Savignac 1934: 575, no. 17, reread by J.T. Milik (1958: 247) and reread again by J. Strugnell (1959: 30) as being indeed 'lktb' dy bgy'. Note that in a yet unpublished inscription from the Sidd al-Ma'jīn in Petra, MP 621, 
it is al-Kutbā who is said to be $b$-gy" ("in Gaia") and it is therefore possible that al-Kutbā lies sometimes behind this anonymous expression. We also find it four times in North-west Arabia, in Dūmah (Savignac and Starcky 1957: $d w \check{s} r^{\prime}$ 'lh gy') and in Umm Jadhāyidh, in ThMNN 688 and UJadhNab 402 where we have $d w \check{s} r{ }^{\prime}$ ' $/ h g y^{\prime}$, as well as in ThMNN 477\#. The latter is the signature of an individual followed by $q d m$ ' $I h g y^{\prime}$, without the god's name. Considering that four inscriptions mention explicitly Dūšarā as the god of Gaia and that 'lh is in the masculine, and since it is likely that the author of ThMNN 477\# was travelling from Petra to Hegra, we can assume that in this text, Dūšarā is meant.

Finally, we find in the Arabian peninsula the expression 'lhy' klhm, "all the gods", both in Hegra and in Umm Jadhāyidh. Since it is also attested twice in Petra, ${ }^{14}$ it is a common way in the Nabataean kingdom to refer to a number of gods when the author of a text does not want to specify which gods are meant specifically. In the two inscriptions from Petra and in ThMNN 200 (JSNab 11), Dūšarā is named first, then "all the gods". The latter are therefore necessarily considered less important because they are not mentioned individually.

Three deities appear more than five times in the Nabataean inscriptions from the Arabian peninsula and can therefore be considered, with caution, as the most popular ones: Dūšarā, Manātū/Manawatū, and Allāt. It is no surprise that the most popular one is Dūšarā $(21 x)$, the main god of the Nabataeans, worshipped throughout the kingdom. ${ }^{15} \mathrm{He}$ is followed by Manātū/Manawatū (10x plus one possible $m[n]$ wt in UJadhNab 391). ${ }^{16}$ Manātū/Manawatū is not attested elsewhere in Nabataea (Alpass 2011: 136) and her popularity is therefore restricted to North-west Arabia. As for 'lt (6x), who is surprisingly not attested in Petra, she appears in inscriptions from Madā’ in Șāliḥ, al- 'Ulā, Umm Jadhāyidh and, what is new, two unpublished Nabataean inscriptions from Qiyāl, north of Sakākā.

One deity, $\check{s} m y^{\prime}$, and one possible deity (or divine attribute), qyšh, appear twice each. Until the recent discovery (2016) of a new attestation of $\check{s}^{\prime} m y^{\prime}$, this divine name was attested in one text only, from Madā'in Șāliḥ, ThMNN 166\# (CIS II 236), copied by Ch. Doughty and read by J.T. Milik (1972: 409-410). The new inscription, 64114_I04\# (published in Nehmé 2017c), was brought to light by M. al-Musa during the excavations of a residential unit built next to the main Nabataean sanctuary of Hegra which is currently being excavated by a team led by the author. It had been reused in the external wall of the unit. In both texts, šmy', which is the emphatic plural of šmy, appears in the phrase $m n q d m \check{s}^{\prime} m y^{\prime}$, where $\check{s} m y^{\prime}$ is expected to be the name of a deity because the expression $m n q d m$, "in the presence of", is almost always followed by a divine name in Nabataean. It should be noted that the texts do not have $m n q d m$ 'lh $\check{s} m y^{\prime}$, "in the presence of the god of Heaven", but simply $m n q d m \check{s} m y$ ', best translated as "in the presence of Heaven". Note also that the main sanctuary of Hegra was composed of an upper and a lower temple, and that the former was tentatively interpreted as being devoted to the worship of the Sun-god (Nehmé 2012b: 159-160). The new inscription, although not directly connected to the temple, may lead us to revise this interpretation and suggest that the upper

J.T. Milik reads ' $l{ }^{\prime} z^{\prime} g y^{\prime} y t^{\prime}$ in line 3 of a signature, but all that can be read on the photograph is ' $l^{c} z^{\prime} g$---- and it is therefore impossible to say whether the epithet "from Gaia" applies also to al- 'Uzzā.

14 CIS II 350 (Turkmāniyyah inscription) and Dalman 1912: no. 28 (MP 619).

15 All from Madā’in Șālị and its suroundings (13x), Umm Jadhāyidh (6x), Sakākā (1x) and Șirwāḥ in South Arabia (x1).

${ }^{16}$ All from Madā’in Ṣālih and its suroundings (8x) and Umm Jadhāyidh (2x), 
temple was devoted to the cult of a supreme divine figure associated with Heaven. In the 2017 report of the Madā'in Șālih Archaeological Project (Nehmé 2017c: 148-149), I already drew attention to the fact that hšmyn and šmy' were, according to J.T. Milik (1972: 410), the most frequent substitutes for YHWH from the Hellenistic period to the Talmudic literature, which led him to suggest a possible Jewish influence in Hegra. Also, in five Aramaic papyri from the Elephantine collection ${ }^{17}$ dated to around $410 \mathrm{BC}$ or before, the god worshipped by the Jews is called $y h w$ 'Ih šmy', "YHW the God of Heaven". Much later, in the late 4th and 5th century $\mathrm{AD}$, the periphrasis "Master of the Sky and of the Earth", or "Lord/Master of the Sky" is often used in the monotheistic Himyarite inscriptions and the authors of these texts are identified as Jewish or Judaeo-monotheists by C. Robin (2015: § F.1, p. 138-141). Even if a Jewish presence is attested in Hegra by the fact that one of the monumental tombs, IGN 12, was owned by a man who is said to be $y h w d y$ ', "Jew" or "Judaean" in the inscription carved on its façade, JSNab 4, dated AD 42/43, it would probably not be reasonable to consider that the main temple of the ancient city was devoted, in the first century AD, to a Jewish god as such. What is certain is that it was devoted to a supreme deity, as is also indicated by the fact that in the Roman period of the site, in the second century, the temple was dedicated to Jupiter of Damascus. ${ }^{18}$ Note that the divine element $\check{s} m$ ' appears in one theophoric name only, ' $b d$-' $^{\prime} l \check{s} m$ ', "servant of the sky/Heaven", in UJadhNab 72.

As for qyšh, who appears under this form in two texts from Hegra, ThMNN 197 (JSNab 8) and ThMNN 205 (JSNab 16), it is not certain whether she is a divine figure or an attribute of Manawatū, who/which is mentioned in association with her: is what is meant "Manawatū and Qayšā" or "Manawatū and her qyš"? J. Healey considers, probably rightly (1993: 119-120), that qyšh is a divine name, which would therefore be attested only in Hegra, just as šmy' above. Note that byt qyšs (with an alif) is said in ThMNN 226 (JSNab 36) to be the temple in which a copy of the legal inscriptions carved on the tomb façades of Hegra were archived.

There are also a number of divine figures which appear only once in the Arabian peninsula. Al'Uzzā ( $l^{\prime} z$ ') is surprisingly attested only once in Hegra whereas she is relatively popular in Petra and becomes popular in the Arabian peninsula at a later period (see below). She appears

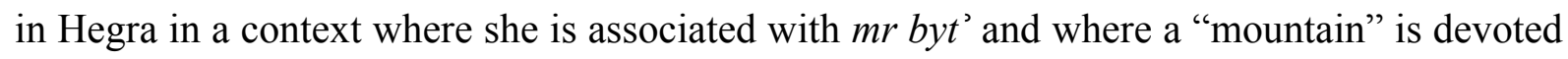
to both of them (MS8Nab1\#). In this very interesting text, the word for "mountain" is $g b l$, which is an Arabic loanword in Nabataean. An alternative meaning for $g b l$, suggested to me by Michael Macdonald, would be to take the Aramaic meaning of GBL, "to give a rounded shape, to knead" (Jastrow, s.v.), hence Syriac gabīlāttā, which can mean "image, work" (Sokoloff, s.v.). However, if what the authors of the text had meant to write was "This is the image of al'Uzzā and the Lord of the house", they would probably have used the word $n s, b$, which occurs in several inscriptions from Petra, one of which says precisely 'lh $n s y b y$ ' ' l' $z$ ' $w m r b y t^{\prime}$, "These

\footnotetext{
17 Cowley 1923: two petitions (nos 27 and 30 lines 27-28, qdm yhw 'lhy šmy') and a duplicate of one of them (no. 31); one answer to the repeated petition (no. 32 line 3, $m d b h^{\prime} d y$ ' $l h$ s smy', "the altar of the God of Heaven"); a letter of recommendation (no. 38 line 3, $\{q d m\}$ ' 'lh šmy' and line 5, b-tll 'lh šmy', "with the help of the God of heaven"); a fragment of a letter (no. 40).

18 This is known from a Latin inscription discovered by D. Gazagne in 2020 in the Hegra temple, 61236_I01, to be published by P.-L. Gatier.
} 
are the betyls of al- 'Uzzā and the Lord of the house", an inscription which is written to the left of an empty niche in which movable betyls were placed on particular occasions. ${ }^{19}$

A 'rā (" $r$ ') is mentioned in a text probably written by someone who came from Boșrā (ThMNN 1 $=$ JSNab 39). In one other text (ThMNN $295=$ JSNab 201) the name is restored.

Four other gods appear also only once. $h b l$ (Hubal) is one of the three gods, along with Dūšarā and Manawatū, to whom a fine should be paid by those who undertake illegal actions in a tomb (ThMNN $206=$ JSNab 16). A god named tbwš (Tabūš?) appears once with Dūšarā in a signature from Madā’ in Șāliḥ, ThMNN 107\# (JSNab 142), the reading of which was checked, but about whom not much can be said in the absence of any parallels. There is also $t d h / t r h$ and $t d h y / t r h y$, for which see the table above. If the reading of DaJ29Nab 1\# is correct, it would provide the first attestation, in Nabataean, of the god $\{r\} s w$, Ruḍā, a deity otherwise widely attested in Safaitic and Thamudic. ${ }^{20}$ The context in which the name appears, almost certainly after $q d m$, makes it highly likely that it is a divine name. Finally, we should perhaps mention the god șlm, not in Nabataean but in a Taymä Aramaic text dated to the 17th year of Malichus II, TA14285+TA14286, for which see Macdonald forthcoming a. This text is interesting because it shows that the main deity of Taymä was still the object of a worship in the first century AD (see also below the theophoric name ' $b d s i m$ ).

This systematic review of the divine names mentioned in the Nabataean inscriptions from the Arabian peninsula is very informative. First, we should note the almost complete absence, in the texts from the Arabian peninsula, of "foreign" gods who were relatively popular in Petra: Atargatis, Ba alšamīn and Isis. ${ }^{21}$ More surprising, especially in Hegra, is the complete absence of ' $b d t$, Obodas, who was very popular in Petra (not only because of the attestations of his cult but also because Obodas was, along with Dūšarā, the only deity worshipped by more than one fraternal society). ${ }^{22}$ It is possible that the cult of Obodas was the closest to what we may think of an "offical" cult and was therefore not practiced outside the Nabataean capital. On the other hand, there are gods who appear in North-west Arabia but not elsewhere in the Nabataean kingdom. This is the case of two pre-Islamic Meccan deities, Hubal and Ruḍā, of two deities from Tayma $\overrightarrow{3}, t d h / t r h$ (which possibly equals $t d h y / t r h y$ ) and $s l m$, the latter in Taymä Aramaic. Finally, three deities with no particular Arabian background, or about which we know nothing, appear in the inscriptions of this region: šmy’, qyšh, tbwš.

Apart from that, the main Nabataean deities, Dūšarā, Manāt/Manawatu and Allāt are well represented in the inscriptions from the Arabian peninsula, and the same is true of the vaguer expressions $m r$ byt', 'lh gy', and 'lhy' klhm.

All in all, and as one might have expected, the religious landscape in the Arabian peninsula as seen through the divine figures mentioned in the Nabataean inscriptions shares common features with that of other regions but it also has regional specificities which were worth noting and which might have escaped the attention of scholars if all the inscriptions known so far had not come under close scrutiny.

\footnotetext{
${ }^{19}$ On this inscription and the niche, see Nehmé 2012a: inscription MP 617, p. 195, and niche 1760.1, p. 120.

${ }^{20}$ References in the OCIANA database online.

21 The list of the deities worshipped in Petra is given in Nehmé 1997: 1044-1045. See also Alpass 2013: 48-49, who, however, questions the definition of these gods as "foreign".

22 On the popularity of Dūšarā and Obodas among the fraternal societies of Petra, see Nehmé 2013: 124 and map p. 125.
} 


\subsection{Names attested in Nabataeo-Arabic and pre-Islamic Arabic only}

The corpus of Nabataeo-Arabic and pre-Islamic Arabic texts is much smaller than the corpus of Nabataean inscriptions and it is therefore to be expected that the number of deities mentioned in them would be much smaller. They are presented in the following table.

\begin{tabular}{|c|c|c|}
\hline Name or expression & No. of attest. & Comment \\
\hline 'l'lh & $\begin{array}{l}3 \mathrm{x} \\
\text { (Nabataeo- } \\
\text { Arabic and } \\
\text { pre-Islamic } \\
\text { Arabic) }\end{array}$ & $\begin{array}{l}\text { Three attestations, one from Himā, north of } \\
\text { Najrān (Himà-Sud PalAr 8\#), one from site } \\
\text { DaJ144, north-west of Dūmah (DaJ144PAr1\#, } \\
\text { Nehmé 2017b), and one from the excavations at } \\
\text { Dūmah (DaJ000NabAr1\#: Nehmé 2017b: 131). }\end{array}$ \\
\hline 'l'zy & $4 \mathrm{x}$ & $\begin{array}{l}\text { Four texts from the Darb al-Bakrah, } \\
\text { UJadhNab } 313 \#, 345 \#, 364 \# \text { and } 368 \# .\end{array}$ \\
\hline
\end{tabular}

The main points which need to be raised are the following. First, there seems to be a real change between the texts written in Nabataean and the $c .160$ ones written in Nabataeo-Arabic and preIslamic Arabic recorded so far (in 2019). The "standard" Nabataean deities who appear in the Nabataean inscriptions, listed above, are not mentioned in any of the texts which belong to the latter two categories. The only exception is al- 'Uzzā, who appears as ' $l i c y$, a spelling which suggests that in the dialect spoken by the authors of these inscriptions, the name of the goddess was pronounced 'uzzay, not 'uzzā. ${ }^{23}$

Another very interesting point is that two texts from Dūmah, one of which is dated to AD 548549 , mention, for the first time in North-west Arabia, 'l'lh, "the god", who is very likely to be equated with the pre-Islamic Arabic name of the Christian God as it appears in other pre-Islamic Arabic inscriptions from Syria (Zabad, AD 512) ${ }^{24}$ and from southern Arabia (Himà-Sud PalAr 8\#, c. AD 469-470), as well as in the foundation inscription of the monastery of Hind in al-Ḥira as it is preserved in the transcriptions of al-Bakrī and Yāqūt (c. AD 560). ${ }^{25}$ It also appears in a recently discovered inscription from Qașr Burqu', in north-east Jordan, written by a Christian. This text (al-Shdaifat et al. 2017) says $d k r$ 'l'lh $y z y d w$ 'lmlk, which the editors translate "May God be mindful of Yazīd the king". The text is not dated but it is convincingly argued in the publication that it is from the reign of the Umayyad caliph Yazīd ibn Mu'âwiyah (AD 680-683). Note finally that ' $l$ 'lh also appears in a theophoric name in the pre-Islamic Arabic inscription from Umm al-Jimāl, LPArab 1\#, as reread by the author.

The Nabataeo-Arabic and pre-Islamic Arabic inscriptions contain many interesting features which will be dealt with elsewhere but one of them is worth being addressed here. They make a more systematic use of the suffix conjugation with an optative force. It is true that the latter is known to have been used in Nabataean Aramaic, for example with L'N, "curse", particularly in the legal inscriptions carved on the monumental tombs of Madāe in Șālih, ${ }^{26}$ and this is

\footnotetext{
23 See Van Putten 2017: 52-53 ("this calls into question whether alternations between final ' and $y$ found in Nabatean should be understood as two different ways of writing the same sound or rather actual phonetic alternation within the Arabic dialects of the speakers who wrote the Nabatean texts"). It seems to me that the second explanation is more likely.

24 On the Zabad inscription see last Macdonald in Fiema et al. 2015: 410-411.

25 See Robin 2008: 185-186. On the date of the Hind monastery inscription, see Robin 2013: 239.

26 JSNab 1, 2, 8, 11, 16, etc.
} 
considered as "one of the hallmark examples of Arabic influence on the Aramaic of the Nabataeans" (Al-Jallad 2015: 105), but it is the first time that it is used with S̆M' (šm ' $t^{~} l^{c} z^{\prime}$ in UJadhNab 313\#, 345\#, and 364\#) and it gives more examples of its use with DKR ( $\underline{d} k r^{\prime} l ' l h$ in DaJ144PAr1\# and DaJ000NabAr1\#).

\subsection{Divine epithet attested in both Nabataean and Nabataeo-Arabic}

One divine epithet only appears in both the Nabataean and the Nabataeo-Arabic scripts. This is mry 'Im', "the Lord of the world", which occurs in both JSNab 17, dated to AD 267 and considered to be still written in the Nabataean script, and UJadhNab 538, dated to AD 303, which is written in a very elegant form of Nabataeo-Arabic. Since UJadhNab 538 mentions Passover and has a Jewish background, $m r y$ ' $/ m$ ' probably refers to the God of the Jews (see the Appendix).

\section{The divine elements in the theophoric names}

Going through the corpus of the Nabataean inscriptions of the Arabian peninsula led to the the recording of 314 theophoric names. These contain $c .42$ divine elements which indirectly reflect the religious landscape in the area and at the period under study. They have, of course, to be treated with more caution than the divine names mentioned as such but they offer a source of information which cannot be ignored.

The data is presented in the table below. When there are too many occurrences of one name, the references are not all given.

\begin{tabular}{|c|c|c|c|}
\hline $\begin{array}{l}\text { Divine } \\
\text { element }\end{array}$ & Theophoric name & Script & Comment \\
\hline ysy & $\begin{array}{l}\text { 'bd-'ysy (2x), ThMNN } 688 \text { and } \\
\text { ThMNN } 13 \text { (ARNA.Nab 53) }\end{array}$ & $\begin{array}{l}\text { Nabataean, with a } \\
\text { samekh. }\end{array}$ & $\begin{array}{l}\text { This is usually considered } \\
\text { as a theophoric name built } \\
\text { with the name of Isis. }\end{array}$ \\
\hline$y \check{s}$ & 'bd-'ys (1x), ThMNN 602\# & $\begin{array}{l}\text { Nabataeo- } \\
\text { Arabic, with a } \\
\text { shin. }\end{array}$ & $\begin{array}{l}\text { It is possible that this name } \\
\text { is the equivalent, in } \\
\text { Nabataeo-Arabic, of } \\
\text { ' } b d^{\prime} y s y \text {. Or it could be ' } b d+ \\
\text { the Arabic name Iyās. }\end{array}$ \\
\hline ' $l / l$ & 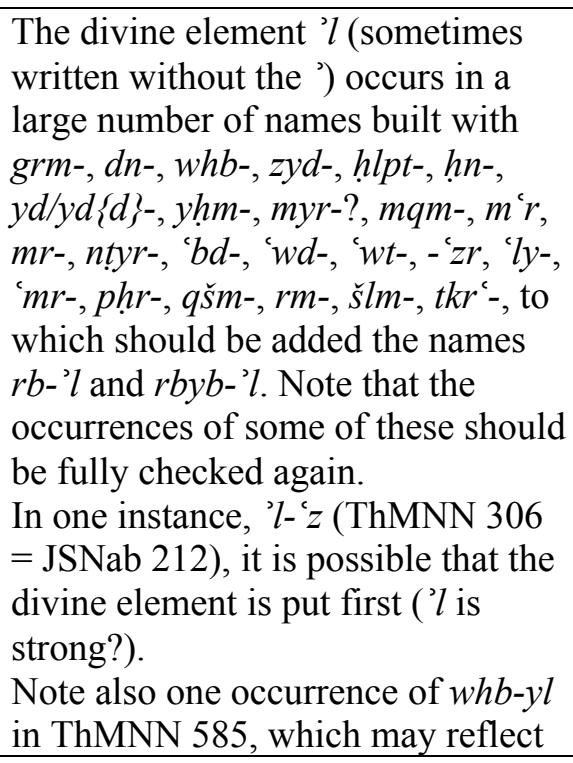 & $\begin{array}{l}\text { Almost all in } \\
\text { Nabataean. The } \\
\text { only names which } \\
\text { occur in } \\
\text { Nabataeao- } \\
\text { Arabic texts are: } \\
\text { - possibly } \\
y d\{d\}^{\prime}\{l\}(1 \mathrm{x}), \\
\text { S } 2 \#, \text { but very } \\
\text { uncertain; } \\
\text { - 'wd'l }(1 \mathrm{x}), \\
\text { UJadhNab } 69 \text { (cf. } \\
\text { Arabic names } \\
\text { 'Awd, } \\
\text { 'Awd̆dmanāt). } \\
\text { - the Jewish name } \\
\text { 'l'zr (2x), }\end{array}$ & $\begin{array}{l}\text { This element and lh/lhy } \\
\text { would require a full } \\
\text { commentary on their } \\
\text { geographical distribution, } \\
\text { on the distribution of the } \\
\text { names where the 'is } \\
\text { assimilated, on those names } \\
\text { which occur only in North- } \\
\text { west Arabia, on the } \\
\text { meaning, etymology and } \\
\text { language of the non divine } \\
\text { element, etc. }\end{array}$ \\
\hline
\end{tabular}




\begin{tabular}{|c|c|c|c|}
\hline & $\begin{array}{l}\text { an } \overline{1} 1 / \overline{\mathrm{el}} \text { pronunciation, as in the } \\
\text { Arabic name Wahbîl. }\end{array}$ & $\begin{array}{l}\text { including one in } \\
\text { UJadhNab } 561 .{ }^{27}\end{array}$ & \\
\hline 'l'lh & 'bd-'l'lh (1x), LPArab 1\# & $\begin{array}{l}\text { Pre-Islamic } \\
\text { Arabic }\end{array}$ & $\begin{array}{l}\text { First attestation of a name } \\
\text { built with ' } b d \text { and 'l'lh. }\end{array}$ \\
\hline 'lktb' & 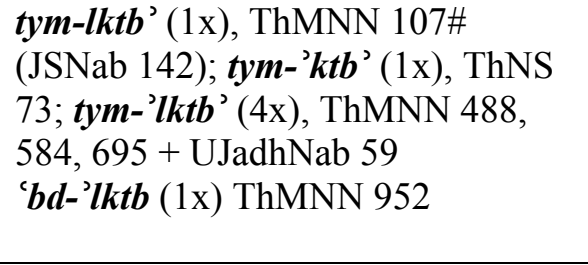 & Nabataean & $\begin{array}{l}\text { Apart from ' } b d d^{\prime} l k t b \text {, which } \\
\text { occurs only in North-west } \\
\text { Arabia, compound names } \\
\text { with 'lktb' are widespread in } \\
\text { various regions of the } \\
\text { Nabataean kingdom. }\end{array}$ \\
\hline${ }^{\prime} l^{c} z^{\prime} P^{\prime} l{ }^{c} z y$ & 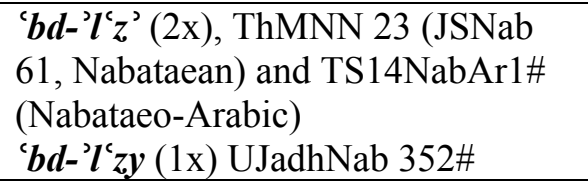 & $\begin{array}{l}\text { Nabataean and } \\
\text { Nabataeo-Arabic } \\
\text { Nabataeo-Arabic }\end{array}$ & \\
\hline 'It & 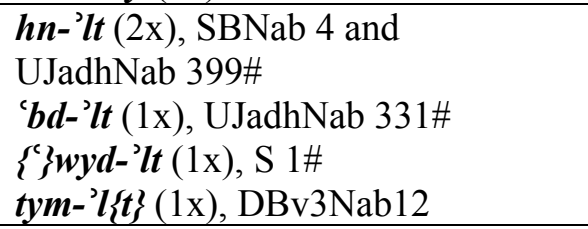 & $\begin{array}{l}\text { Nabataean } \\
\text { Nabataeo-Arabic } \\
\text { Nabataeo-Arabic } \\
\text { Nabataean } \\
\end{array}$ & $\begin{array}{l}\text { These four compound } \\
\text { names are attested only in } \\
\text { North-west Arabia. }\end{array}$ \\
\hline$b l$ & $\begin{array}{l}\boldsymbol{r y y \boldsymbol { m }}-\boldsymbol{b l}(1 \mathrm{x}), \text { ThMNN } 583 \\
\boldsymbol{y} \boldsymbol{d}^{c}-\{\boldsymbol{b} \boldsymbol{l} \boldsymbol{l}(1 \mathrm{x}), \text { ThMNN } 870 \\
\boldsymbol{y} \boldsymbol{t y}-\boldsymbol{b} \boldsymbol{l}(1 \mathrm{x}), \text { ThMNN } 644\end{array}$ & All Nabataean & $\begin{array}{l}\text { The first one also appears } \\
\text { once in Petra (RES 1427D). }\end{array}$ \\
\hline$b^{c} l$ & 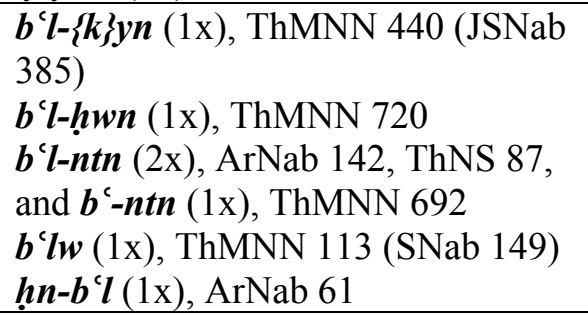 & All Nabataean & $\begin{array}{l}\text { All these names except } \\
b^{`} \text { Intn are attested only in } \\
\text { North-west Arabia. }\end{array}$ \\
\hline$g^{\prime}$ & ${ }^{\prime} \boldsymbol{b d} \mathbf{-}^{\prime} \lg ^{\prime}(18 \mathrm{x})$ & $\begin{array}{l}\text { All Nabataean } \\
\text { except one, } \\
\text { UJadhNab 536, } \\
\text { Nabataeo-Arabic }\end{array}$ & $\begin{array}{l}\text { This name is widespread in } \\
\text { Nabataean and is usually } \\
\text { considered to mean "the } \\
\text { servant of [the god of] Gaia } \\
\text { [Petra]". }\end{array}$ \\
\hline$g d$ & $\begin{array}{l}\boldsymbol{g d - t} \boldsymbol{b}(3 \mathrm{x}), \text { ThMNN } 127 \\
\text { (JSNab 163), ThMNN 166\# } \\
\text { (CIS II 236), and ThMNN } 128 \\
\text { (JSNab 164), all from Madā'in Șālih }\end{array}$ & All Nabataean & $\begin{array}{l}\text { Theophoric names built } \\
\text { with Gad are attested in } \\
\text { North-west Arabia and in } \\
\text { the Hawrān. }\end{array}$ \\
\hline$g y r$ & whb-'lgyr (1x) UJadhNab 428 & $\begin{array}{l}\text { Nabataean } \\
\text { (bilingual } \\
\text { Nabataean- } \\
\text { Ancient South } \\
\text { Arabian) }\end{array}$ & $\begin{array}{l}\text { First attestation of this name } \\
\text { in Nabataean. One of the } \\
\text { meanings of } j \bar{a} r \text { in Arabic is } \\
\text { "protector, one who protects } \\
\text { another from that which he } \\
\text { fears" (Lane } 1863-1893 \text { : } \\
\text { 483c), thus "gift of the } \\
\text { protector"? }\end{array}$ \\
\hline$d w \bar{s}^{2}{ }^{2}$ & 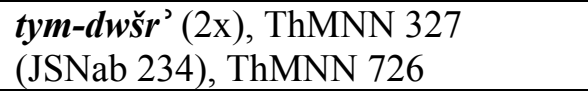 & Nabataean & Very widespread name. \\
\hline$h b l$ & bn-hbl (1x), ThMNN 539\# & Nabataean & $\begin{array}{l}\text { In North-west Arabia, in } \\
\text { Petra (Milik and Starcky } \\
\text { 1975: no. 5, p. 120-122, }\end{array}$ \\
\hline
\end{tabular}

${ }^{27}$ The other occurrence of ' $l z z r$, "God's help" is in papyrus Starcky 1954, for which see now Yardeni 2001. 


\begin{tabular}{|c|c|c|c|}
\hline & & & $\begin{array}{l}b r h b l) \text { and in Puteoli (CIS II } \\
158, b n h b l) \text {. }\end{array}$ \\
\hline$h w r$ & $\begin{array}{l}\text { tym-'llhwr (2x), ThMNN } 497 \text { and } \\
595\end{array}$ & Nabataean & $\begin{array}{l}\text { It is not certain whether } h w r \\
\text { is a divine name or not. It is } \\
\text { not attested elsewhere } \\
\text { (although the name 'lhwr } \\
\text { exists). }\end{array}$ \\
\hline lh/lhy & 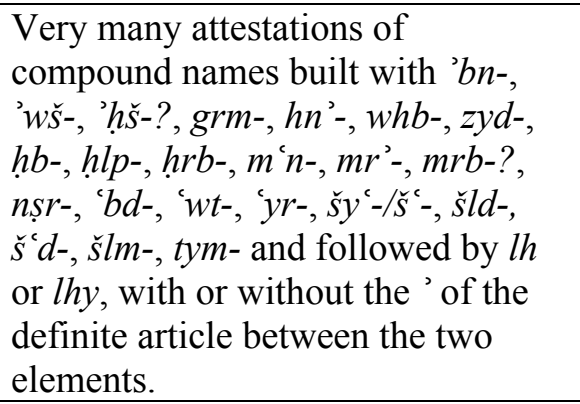 & $\begin{array}{l}\text { All Nabataean } \\
\text { except one } \check{s} y^{(’} l h y \\
\text { in Nabataeao- } \\
\text { Arabic in } \\
\text { ThMNN 862\# }\end{array}$ & $\begin{array}{l}\text { Same comment as for ' } l / l \\
\text { above. }\end{array}$ \\
\hline llh & $\begin{array}{l}\text { One possible attestation in the name } \\
\text { \{sld }\} \text {-llh in UJadhNab 352\# (see the } \\
\text { comment in the appendix). }\end{array}$ & Nabataeo-Arabic & \\
\hline$m n w t w$ & 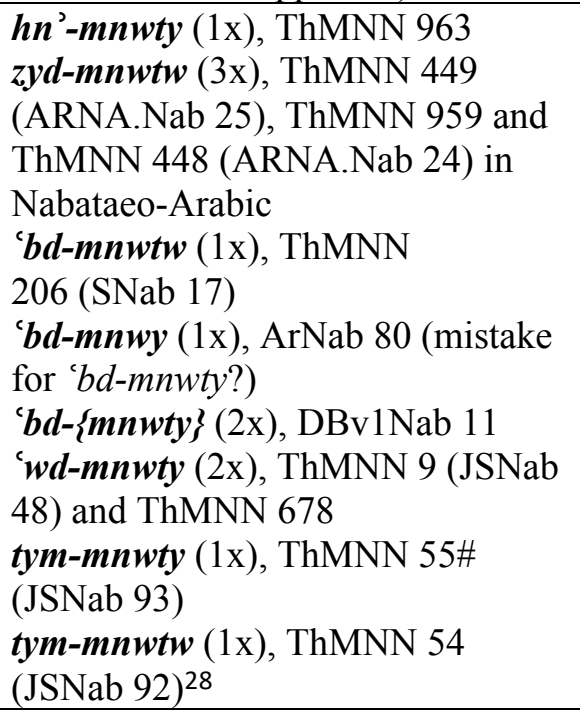 & $\begin{array}{l}\text { Nabataean } \\
\text { Nabataean and } \\
\text { Nabataeo-Arabic } \\
\text { Nabataean (3rd c.) } \\
\text { Nabataean } \\
\text { Nabataean } \\
\text { Nabataean } \\
\text { Nabataean } \\
\text { Nabataean }\end{array}$ & $\begin{array}{l}\text { Note the genitive case- } \\
\text { ending in } h n^{\prime} m m n w t y \text { and } \\
\text { others. Note also that in } \\
\text { theophoric names, the name } \\
\text { of the goddess is always } \\
\text { spelled } m n w t w / m n w t y, \\
\text { never } m n t w / m n t y \text {. } \\
\text { Compounds with } m n w t w \text { are } \\
\text { attested only in North-west } \\
\text { Arabia. }\end{array}$ \\
\hline mnpw & $\begin{array}{l}\text { 'bd-mnpw (1x) WRPAr3\# from } \\
\text { Wadi Ramm }\end{array}$ & $\begin{array}{l}\text { Pre-Islamic } \\
\text { Arabic }\end{array}$ & $\begin{array}{l}\text { Cf. the Arabic name } \\
\text { 'Abdmanāf. }\end{array}$ \\
\hline$m \check{s} y h$ & $\begin{array}{l}\text { 'bd-'Imšy }(1 \mathrm{x}), \text { Himà-al- } \\
\text { Musammăt PalAr } 5\end{array}$ & $\begin{array}{l}\text { Pre-Islamic } \\
\text { Arabic }\end{array}$ & $\begin{array}{l}\text { Cf. the Arabic name } \\
\text { 'Abdalmasīh. }\end{array}$ \\
\hline ' $b d t$ & $\begin{array}{l}\text { A large number of theophoric names } \\
\text { are built with the name of the } \\
\text { deified Nabataean king Obodas } \\
\text { following the words 'wš-, tym-, ' } b d-\text {-. } \\
\text { The name ' } b d t \text { (and its diminutive } \\
\text { form 'bydt) itself is also used as a } \\
\text { name. }{ }^{29}\end{array}$ & All Nabataean & $\begin{array}{l}\text { This very popular } \\
\text { Nabataean name, the only } \\
\text { one with tymdwšr which } \\
\text { occurs in all the regions of } \\
\text { the Nabataean kingdom, } \\
\text { never appears in the } \\
\text { Nabataeo-Arabic } \\
\text { inscriptions. }\end{array}$ \\
\hline șlm & $\begin{array}{l}\text { cbd-sslm (3x), ThMNN 701\#, } \\
\text { HNNUT 7, UJadhNab 383. }\end{array}$ & All Nabataean & $\begin{array}{l}\text { This compound is attested } \\
\text { only in North-west Arabia, }\end{array}$ \\
\hline
\end{tabular}

28 JSNab 92 and JSNab 93 are written one above the other, one has tymmnwtw and one tymmnwty.

${ }^{29}$ Note that since Obodas is the only deified Nabataean king, compound names built with kings' names other than 'bdt (hrtt, rb'l, mnkw/mlkw) are basileophoric rather than theophoric and have therefore not been taken into consideration in this paper. 


\begin{tabular}{|c|c|c|c|}
\hline & & & $\begin{array}{l}\text { which is not surprising since } \\
\text { slm is the god of Taymä. }\end{array}$ \\
\hline$q y \check{s}$ & $\begin{array}{l}\boldsymbol{m} \boldsymbol{r}^{2}-l \boldsymbol{q} \boldsymbol{y} \mathbf{s}^{(3 \mathrm{x})} \text { MAIS 2\#, Himà-Sud } \\
\text { PalAr } 5 \text { and Himà-Sud PalAr 8\# }\end{array}$ & $\begin{array}{l}\text { All Pre-Islamic } \\
\text { Arabic }\end{array}$ & $\begin{array}{l}\text { This name does not occur in } \\
\text { the Nabataean texts. }\end{array}$ \\
\hline$q s$ & 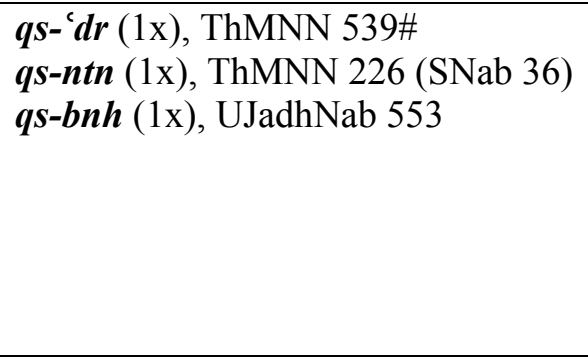 & All Nabataean & $\begin{array}{l}\text { These names are built with } \\
\text { the name of the Edomite } \\
\text { deity Qōs. Qsntn and qsbnh } \\
\text { is attested only in North- } \\
\text { west Arabia; according to } \\
\text { A. Negev, } q w s^{c} d r \text { is attested } \\
\text { in Sinai-Egypt-Negev (not } \\
\text { checked). }\end{array}$ \\
\hline$\stackrel{s}{s} m^{\prime}$ & 'bd-'lšm' (1x) UJadhNab 72\# & $\begin{array}{l}\text { Mixed Nabataean } \\
\text { and Nabataeo- } \\
\text { Arabic }\end{array}$ & $\begin{array}{l}\text { cf. } \check{s} m y^{\prime} . \text { This is the only } \\
\text { name built with } \check{s}^{\prime} \text { ? }\end{array}$ \\
\hline$\check{s} m \check{s}$ & $\begin{array}{l}\text { 'bd-šm̌s (1x), ThNIS } 11 \\
\text { šmš (1x) DaJ29Nab5 } \\
\text { šmš-grm (2x) CIS II } 331 \text { and } \\
\text { DaJ29Nab2 (unpublished) }\end{array}$ & All Nabataean & Only in North-west Arabia. \\
\hline
\end{tabular}

The most popular Nabataean theophoric names, which are attested in several regions of the Nabataean realm ( $\left.w h b^{\prime} l h y,{ }^{\prime} b d^{c} b d t, \check{s}^{c} d^{\prime} l h y, t y m d w s^{\prime} r^{\prime}\right)$ are well represented in the inscriptions written in Nabataean characters in North-west Arabia, in a number of sites, and this is not particularly surprising. What is interesting, however, is that none of these names appears in texts written in Nabataeo-Arabic or pre-Islamic Arabic characters.

Out of the 314 theophoric names collected in the corpus of inscriptions I examined, 74 names (names or orthographic variants of names) are attested only in North-west Arabia, most of them only once. Among them, c. 52 were not previously listed in A. Negev's list of names published in 1990 (quite a few of them appear in inscriptions published since then). It would be interesting to make a list of those names which are only written differently in North-west Arabia. This aspect of the description of the names, however, was not initially recorded in the database and would therefore require some additional work to be dealt with. It would allow to determine whether some differences appear more consistently than others. These are, as far as I can tell (but the list is not exhaustive):

- the assimilation or not of the ' of the article before -lh and -lhy (e.g. 'wtlhy versus ' $w t^{\prime}$ 'lhy, hblhy versus $\left.h b^{\prime} l h y\right)$;

$--y l$ for $-' l$, for example whbyl instead of $w h b^{\prime} l$, which may reflect an $\overline{1} 1 / \bar{e} l$ pronunciation (imālah?); 30

- the $-y$ versus the -' or $-w$ endings (tymmnwty versus tymmnwtw and ' $b d^{\prime} l^{c} z y$ versus ' $b d^{\prime} l^{c} z$ '), to which should be added the case of new names with a $-y$ ending (' $w d m n w t y$ );

Other orthographic differences may simply be mistakes on the engraver's part ( $b^{\text {‘ntn }}$ for $b^{\text {'lntn, }}$ 'bdmnwy for 'bdmnwty?). Note also that the name ' $b d$ 'lktb' is written once without the final '.

As for the names themselves, one should note the popularity in North-west Arabia of names referring to the goddess $m n w t w$, who appears in several names which are not attested elsewhere:

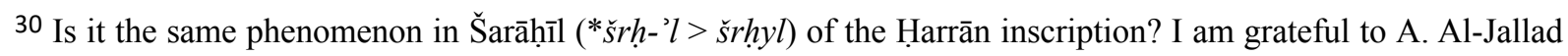
for drawing my attention to that.
} 
$h n^{\prime} m n w t w, z y d m n w t w, ' b d m n w t w /{ }^{\prime} b d m n w t y$, and ' $w d m n w t y$. Among the new names, it is worth noting $h n^{\prime} l t$ (compare with $h n^{\prime} l h y$ ) and 'bdšmš. Note also the very interesting three attestations

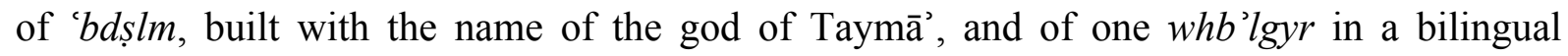
Nabataean-ASA text.

One may also point to the use of new non-divine elements such as hlpt-, phrr-, ' $w d-$. Again, it would be interesting to examine not only these new elements but all the non-divine elements attested in North-west Arabia and determine whether they are Aramaic, Aramaic or Arabic, or Arabic. If a number of them turn out to be clearly Arabic, this would indirectly - because they are used in personal names - increase the number of Arabic loanwords attested in this region. If we look now at the names which occur in the inscriptions written in Nabataeo-Arabic and pre-Islamic Arabic characters, the following remarks can be made:

- as said above, the most popular theophoric names attested in the Nabataean inscriptions are completely absent from the corpus of Nabataeo-Arabic and pre-Islamic Arabic texts;

- the most popular divine figures mentioned in the theophoric names in Nabataeo-Arabic texts are ' $l ' z$ ' and ' $l t$, both attested twice each;

- a theophoric name built with 'l'lh, "the God", ' $b d^{\prime} l$ 'lh, appears for the first time in a preIslamic Arabic text from Umm al-Jimāl in Jordan. It is not particularly surprising since the divine figure 'l'lh itself does not appear in the inscriptions before the beginning of the 6th century AD, in AD 512 in Zabad, in AD 548-549 in the area of Dümah and around AD 469 in Najrān. It is not certain whether šldllh is also a compound built with 'l'lh.

- the only theophoric names which appear in both Nabataean and Nabataeo-Arabic are ' $b d^{\prime} l l^{c} z$ ',

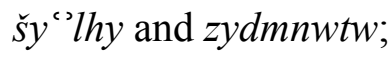

- a few theophoric names appear only in pre-Islamic Arabic. These are ' $b d^{\prime} l$ ' $l h$, already mentioned above, 'bdmnpw ('Abdmanāf) in Wadi Ramm, ${ }^{31} m r^{\prime} l q y s ̌$ (in texts form Hịmā, in Zabad, and in Namārah), and ' $b d^{\prime} l m s ̌ y h$ ('Abdalmasīh, in Himā only). They seem therefore to be new in the onomasticon of the pre-Islamic Arabic inscriptions of the Arabian peninsula;

- the following names, finally, appear only in Nabataeo-Arabic: ' $b d^{\prime} y s$ (but see above, this may be an orthographic variant of ' $b d^{\prime} y s y$ or the name 'Abd+Iyās), $y d\{d\}^{\prime}\{l\}$ (but the reading is quite uncertain), 'wd'l, 'bd'lt, \{'\}wyd'lt, 'bd'lšm'.

\section{Other remarks}

The contents of the hundreds of inscriptions examined in this study raise many issues which could not all be developed in this contribution. They will be addressed later and are mentioned here only for possible discussion:

- dkr/dkyr: the Nabataeo-Arabic and pre-Islamic Arabic inscriptions from the Hijāz sometimes use $d k y r$ (Aramaic passive participle), sometimes dkr/dkrt (the perfect 3rd person masculine/feminine, possibly with an optative force), and sometimes neither. It is worth pointing out here that $d k y r$ is never used in the 6th century texts, only $d k r$ is. Besides, it is not followed, as in most of the Nabataean graffiti, by a personal name, but by a divine name. ${ }^{32}$ This

\footnotetext{
31 And see 'mtmnpw in Zabad.

32 Note however that the feminine, $d k r t$ followed by the name of the goddess ' $l t$ is attested in five Nabataean inscriptions: JSNab 212, 213 as well as Savignac 1933: nos. 3, 7, 8 and 9 (in the latter, the goddess' name is spelled 'ltw.
} 
is true in DaJ144PAr1, the AD 548-549 inscription from Dūmah ( $\left.d k r^{\prime} l^{\prime} l h\right),{ }^{33}$ as well as in DaJ000NabAr1, the undated but probably middle to late-fourth century AD text from the excavations at Dūmah. Note that both $d k y r$ and $d k r$ are completely absent from the Najrān inscriptions. This formula, a verb in the perfect with an optative force followed by a divine name, is paralleled in the four unfortunately undated Nabataeo-Arabic texts from Umm Jadhāyidh which start with šm ' $t$ followed by ' $l{ }^{\prime} z y$. Rather than an Arabic "influence", these uses of $d k r$ and $\check{s} m^{\prime} t$ suggest strongly that the authors of these texts were Arabic speaking people. - bn/br: as was pointed out by Macdonald (2010: note 41), $b r$ is always used instead of $b n$ in the pre-Islamic Arabic inscriptions, and this is also true in the ones which have been examined in the course of this study. $b r$ was therefore considered as a "fossil", very much like šlm, $d k y r$ and $b t b$.

- some names show a genitive case ending: hn'mnwty, 'bdmnwty, 'wdmnwty and tymmnwty, which all happen to be written with the mnwt spelling of the deity's name;

- the divine name ' $l^{c} z y$ and the theophoric name ' $b d^{\prime} l^{c} z y$ point to a pronunciation *-ay of the divine name al-'Uzzā;

- the definite article in the compound names is sometimes written ' $l$, sometimes ' and is sometimes absent. It might be worth looking more closely at the distribution and treatment of the definite article in these names;

- the disappearance of the samekh from the inscriptions written in Nabataeo-Arabic: to my knowledge, the latest dated example of samekh used in a text is to be found in JSNab 386 (AD 306), in the month name sywn (if the reading is correct). It is therefore not surprising that it does not occur in any Nabataeo-Arabic text except one, ThMNN 556 (UJadhNab 219), in the name ywsp. This text, however, does not seem to me to be later than the 4th century AD. It is interesting to see that the name built with the name of the goddess Isis, 'bd'ysy in Nabataean characters, seems to be written ' $b d^{\prime} y y^{\prime}$ in Nabataeo-Arabic, in ThMNN 602\# (unless this is the name 'Abd'iyās, which does not exist in Ibn al-Kalbī's genealogies). It is possible that at a certain period of time, the Nabataeo-Arabic character $\breve{s}$ became used to write 'pure' [s].

- a number of new theophoric names appear in the inscriptions recently published or still unpublished but since I have not specifically distinguished those from the ones which are listed in Negev's Personal names, I cannot provide a list for the moment.

\section{Concluding remarks}

To summarize briefly, the present study has shown the following:

- there are local influences as well as regional and chronological specificities in the way divine and theophoric names are distributed but the most popular Nabataean names are widespread throughout the Nabataean kingdom;

- the Syrian and Egyptian deities, who were very popular in Petra (Atargatis, Ba alšamīn, Isis, etc.) are completely absent from North-west Arabia, including in Madā’ in Șālih;;

- if one takes into consideration the divine names $t d h / t r h$ and $t d h y / t r h y$ as well as the mention of $s$ lm both in a first century AD Taymä $\bar{a}^{2}$ Aramaic text from Taymä and in the theophoric name

\footnotetext{
33 In this text, $d k r$ is written once in Nabataeo-Arabic characters in the first line and once in Arabic characters in the second line. See Nehmé 2017b: 128-129.
} 
'bds $l m$, attested in three texts from North-west Arabia (and nowhere else), it appears that the cult of the Taymä' deity Șalm was still relatively popular in this area of the Nabataean kingdom; - some of the names show orthographic variants, although this aspect needs a much closer examination;

- the worship of a god named $\check{s} m y^{\prime}$ at Hegra was made clearer by the discovery in the Madâ' in Saālih excavations of a new inscription mentioning it as well as by the new theophoric name 'bd'lšm' in a Nabataeo-Arabic text;

- the Nabataeo-Arabic inscriptions show the (relative) popularity of ' $l t$, ' $l{ }^{c} z$ ' and mnwtw. This is not particularly surprising since they are the three major goddesses of pre-Islamic Mecca, but it is the first time that their preeminence in the fourth to fifth century AD inscriptions from Arabia is demonstrated;

- one divine epithet only, mry ' $/ m$ ', is attested in both the Nabataean and Nabataeo-Arabic scripts (in the latter as the God of the Jews) but in two inscriptions which are only 36 years apart.

- the name given to the pre-Islamic Christian god, ' $l ' l h$, is now found in a 6th century AD preIslamic Arabic text from the Hijāz;

- there seems to have been, in the Hijāz, at the period represented by the Nabataeo-Arabic and pre-Islamic inscriptions, three major female divine figures and one major male figure. The latter is not Dūšarā but Al'ilāh, "God" who, in the 6th century, becomes widespread from Syria to Najrān. The religious landscape of northern Arabia thus seems to have witnessed a change which is visible in the inscriptions recorded in the three successive categories of scripts distinguished in this study.

\section{Appendix: a selection of the inscriptions mentioned in the text}

Note: the inscription numbers are those given within each project or publication. They are presented in alphabetical order of the sigla.

\section{- 64114 I04}

Nabataean, Madā'in Șāliḥ. Inscription discovered during the Madā’in Șāliḥ 2016 excavation season in the so-called "residential unit", south-west of the Nabataean sanctuary IGN 132. Published in Nehmé 2017c.

[Insert here Nehme_fig01_64114_I04 and the following caption: Photo M. al-Mūsā, facsimile L. Nehmé]

Reading (no. 4 on the copy):

šlm ș----m br k----

hn't mn qdm šmy'

"May Ș[1]m son of K---- [son of]

Hn't be safe, in the presence of Heaven".

Compare with ThMNN 166 (CIS II 236) below. 


\section{- DaJ000NabAr1 (= DaJTrans1)}

Nabataeo-Arabic, Dūmat al-Jandal. Published in Nehmé 2016, with a new reading in Nehmé 2017b: 130-131. Inscription discovered at the bottom of the collapse layer of a tower located on top of the outcrop which overlooks the so-called western settlement of Dūmah from the south. This collapse layer yielded pottery dated to the interval between the 1 st and the 4th century AD (Charloux et al. 2016: 227-228) as well as a Roman coin dated to the reign of Licinius (AD 308-324) which gives a terminus post quem to the inscription.

[Insert here Nehme_fig02_s and the following caption: Photo G. Charloux and facsimile L. Nehmé]

$[d] k r$ 'l'lh

$m l k w$ br $\{.$.

$h y\{h\} w$

$t\{b / y\} h h$

"May God [re]member Mālikū son of Ḥayyah and Tābihnah".

- DaJ29Nab1

Nabataean, Qiyāl (a Nabataean site c. 15 km northwest of Sakākā). Previously unpublished. [Insert here Nehme_fig03_DaJ29Nab1_DJ2012a1031B.JPG and the following caption: Photo G. Charloux]

dkyryn

$m s ̌ l m w<m\{n\}>m n$

hyw

$q d m\{r\} s+w$

"May Muslim (?) and Hayy be remembered in the presence of Ruḍā".

This text is difficult to read because the order of the words as they are written on the stone is peculiar. Mn qdm should be read after hyw, the author intending, most probably, to write dkyryn mšlm w hyw mn qdm \{r\}șw. Dkyryn being in the plural, at least two names are expected. The name $m s ̌ l m$ is attested alongside the more common $m s ̌ l m w$. If the reading is correct, this text may provide the first attestation of Ruḍa in the Nabataean inscriptions.

\section{- DaJ29Nab13}

Nabataean, Qiyāl. Previously unpublished.

[Insert here Nehme_fig04_DaJ29Nab13_DJ2012a1088B.JPG and the following caption: Photo G. Charloux]

dkyr h̆rtt

mn qdm 'lt

"May Ḥāritat be remembered in the presence of Allāt".

The text is obscured by letters which belong to another inscription but the reading is certain.

- DaJ29Nab24

Nabataean, Qiyāl. Previously unpublished.

[Insert here Nehme_fig05_DaJ29Nab24_DJ2012a1122B.JPG and the following caption: Photo G. Charloux] 
$d k r t$ 'lt šlmw br

'drmw btb l'lm

"May Allāt remember Sālim (or Sallām) son of 'Adramū in well-being for ever".

- DaJ144PAr1

Pre-Islamic Arabic, Site 144 northwest of Dūmah. Published in Nehmé 2017b.

[Insert here Nehme_fig06_DaJ144PAr1_DJ2016a0150B.jpg and the following caption: Photo

G. Charloux, facsimile L. Nehmé]

$d k r$

$d k r$ 'l'lh

$h g^{c}\{b / n\} w b r$

šlmh

$\{b\} y\{r\}[h] \quad \check{s} n t 4 x 100$

$+20+20+3$ cross

"May remember. May God remember $\operatorname{Hg}^{c}\{b / n\} w$ son of Salama/Salāma/Salima $\{$ in $\}$ the $\mathrm{m}$ [onth] (gap) year 443".

This very interesting text, the author of which was probably Christian because of the cross which follows the date, is the first pre-Islamic Arabic text dated to the sixth century ever discovered in North-west Arabia. It is dated to AD 548-549. For a full commentary, see Nehmé $2017 \mathrm{~b}$.

\section{- Himà-Sud PalAr 8}

Pre-Islamic Arabic, Ḥimā, north of Najrān. Published in Robin et al. 2014: 1099-1102, fig. 8, 41-42.

[Insert here Nehme_fig07_Himà-Sud PalAr 8.jpg and the following caption: Photo C. Robin, facsimile L. Nehmé]

Reading as in Robin et al. 2014: 1100.

(Cross) Twbn br mrtd

'ly' br mr'lqyš br tymw

'l'lh ----

"Tawbān son of Martad

Elie son of Imru' al-Qays son of Taymū

God ----”.

The first two lines are signatures by two different individuals and are not connected with each other except by the fact that they are written one above the other. What follows ' $l$ 'lh is not clear. This text belongs to the same group as Himà-Sud PalAr 1 (Robin et al. 2014: 1087-1092, fig. $10,11,29)$, dated to AD 469-470, and it is probably dated to around the same time.

- LPArab 1

Pre-Islamic Arabic, Umm al-Jimāl. Published in Littmann 1949 and others, see also alGhabban 2008: fig. 36-38.

[Insert here Nehme_fig08_LPArab1 and the following caption: Photo L. Nehmé] 
This difficult text requires a new full edition, especially since the stone on which it is written is now stored in the Mafraq museum in Jordan, where it can be examined. ${ }^{34}$ Until this is done, I would only like here to suggest to read the end of the first line as ' $b d^{\prime} l$ 'lh, 'Abd'al'ilāh, a theophoric name built with ' $b d+{ }^{\prime} l ' l h$.

- MAIS 2 (Sakākā)

Pre-Islamic Arabic, Sakākā. Published in al-Muaikil 1993: no. 2.

[Insert here Nehme_fig09_MAIS2_DJ2011a0774.jpg and the following caption: Photo

G. Charloux and facsimile L. Nehmé]

$b\{c y\}\{s\} w$

dkyr $m r^{2} l q y \check{s}$

br mlkw

"Ba\{ỵ̣\} (?). May Imru' al-Qays son of Mālik be remembered".

On the photograph, two letters are carved before the first word of the pre-Islamic Arabic text. They are carved a little higher and are not likely to belong to the text. The stroke of these two letters is thicker than those of the pre-Islamic text, the patina is lighter and there seems to be two dots below the first letter (a $y$ ?). For these reasons, it is probably (much?) later.

The first line of the text is difficult to read. The first letter can be a $b$ or a $n$. The second one is likely to be a 'although a $y$ is also possible. The third one cannot be a $k$ if one compares it with the $k$ in $m l k w$. No satisfactory Arabic name starting with $\mathrm{Na}^{c}-$ or $\mathrm{Ba}^{c}-$ was however found. If read $b y^{c} w$, it could be the equivalent of Arabic Bayḍ. The second and third line of the text are clear.

\section{- MS8Nab1}

Nabataean, Madā'in Șāliḥ. Published in Nehmé 2005-2006: no. 12, p. 189-194, fig. 134.

This text is carved on a terrace above a Nabataean monumental tomb (IGN 1), to the right of the drawing of two joint betyls, an eye-betyl on the left representing al- 'Uzzā and a plain betyl on the right representing the Lord of the house.

[Insert here Nehme_fig10_MS8Nab1.jpg and the following caption: Photo and facsimile L. Nehmé]

dnh $g b l^{\prime} l^{\prime} z^{\prime} w$ mr byt'

"This is the mountain of al- 'Uzzā and the Lord of the house".

Note the probable Arabic loanword $g b l$, "mountain". This text is interesting because it shows that a "mountain" could be devoted to gods, in the present case one of the sandstone outcrops of the Jabal al-Mahjar in Madā’ in Șālih. Mr byt' is probably a periphrasis for a major Nabataean god, possibly Dūšarā.

\section{- QNNab 5}

Nabataean, Q⿱āe an-Nqayb (Darb al-Bakrah). Published in Nehmé 2018.

[Insert here Nehme_fig11_QN5.jpg and the following caption: Photo and facsimile L. Nehmé] šlm 'byw

$b r$

\footnotetext{
${ }^{34}$ Information given by Ali al-Manaser.
} 
šld'lhy

"May Ubayy son of Šald'allāhī be safe".

The name šld'lhy appears here for the first time in Nabataean. There is no radical SLD in Arabic but Aramaic šeled, "a mass of a burnt or decayed body distinguishable in shape and outlines" (Jastrow, s.v.) is a particularly unfortunate compound for a theophoric name.

- S 1

Nabataeo-Arabic, Sakākā. Published in Nehmé 2010: 71-72.

[Insert here Nehme_fig12_S1.jpg and the following caption: Photo courtesy Kh. al-Muaikil and facsimile L. Nehmé]

dkyrw mhrbw w'ṣhbh

'l '̌s $r h w$ 'nymw w [w]'lww hrtw w $\{k\} h$ šs

btbw mhrbw br 'wyd'lt ktb ydh ywm ‘̌rh

w tmnh b'yr šnt 2x100+100+20+3 \{'d.hg \}---- 'l hyrh

"May Muḥārib and his ten companions and Ġunaym (?) and Wā̀il and Hārit and $\{\mathrm{K}\}$ ḥšw be remembered in well-being. Muhārib son of 'Awīd'allāt wrote [with] his hand day eighteen of Iyyār year 323\{\}$\{d\}\{.\}\{h g\}^{----}$al-Hīrah?/the camp?”.

The text is dated to AD 429. 'Awī $\underline{d}$ 'allāt means "the refuge of Allāt". What precedes 'lhyrh is not clear and would require examining the text on the rock. Its precise location is however unknown.

- S 2

Nabataeo-Arabic, Sakākā. Previously unpublished.

[Insert here Nehme_fig13_S2 and the following caption: Photo courtesy Kh. al-Muaikil]

According to Kh. al-Muaikil, this text comes from the same outcrop as the previous one. The reading is uncertain and it is given here for sake of completeness.

dkyr $\{b\} l y b t b\{w\}$ šlm

$w \operatorname{mhl}\{d\}$---- $l\{b\}\{y / n\} w$ br $y d\{d\}^{\prime}\{l\}$

No translation is given of this text the reading of which remains uncertain. The second word is possibly the exclamative particle $b l y$, "Yea!". On the third line, $m h l\{d\}$ was preferred to $m h l\{w\}$ because the loop of the letter is not closed at its top. The name may correspond to Arabic Muhallad. The last name, which is the one which interests us here, is also uncertain because the last letter could be a badly formed final $h$ while the second $d$ is very uncertain. The only reason why this text is presented here is because it would be the only example of a theophoric name with -' $l$ in Nabataeo-Arabic.

- ThMNN 55 (JSNab 93)

Nabataean, Madā’ in Șāliḥ.

[Insert here Nehme_fig14_ThMNN55_JSNab93 and the following caption: Photo L. Nehmé] šlm tymmnwty

"May Taymmanawatī be safe". 
- ThMNN 107 (JSNab 142)

[Insert here Nehme_fig15_ThMNN107_JSNab 142 and the following caption: Photo L. Nehmé]

Nabataean, Madā’ in Șāliḥ.

dkyr tymlktb'

$q d m d w \check{s} r^{\prime} w t b w \check{s}$

"May Taymalkutbā be remembered in the presence of Dūšarā and Tabūšs".

In the second line, one expects $t b w s$ to be a divine name because it is coordinated to $d w \check{s} r$ '

- ThMNN 166 (CIS II 236)

Nabataean, Madā'in Șāliḥ. Copied by Ch. Doughty (1884: pl. XI, fol. 18) and read correctly in Milik 1972: 409-410. See also Nehmé 2017c.

[Insert here Nehme_fig16_CISII236 and the following caption: Photo and facsimile L. Nehmé] dkrwn th lzydw br gdṭ

br zydw mn qdm šmy’

$\{z y d w\}$

"Good remembrance to Zaydū son of Gadțab son of Zaydū in the presence of Heaven. \{Zaydū $\} "$

- ThMNN 477 (UJadhNab 88)

Nabataean, Umm Jadhāyidh. Also published in Nehmé 2018.

[Insert here Nehme_fig17_UJadh 88 and the following caption: Photo and facsimile L. Nehmé] ' $\{d / r\}\{d / r\}$ y br $m\{y / n\}^{\prime} d k y r$

btb mn qdm 'lh

$g\{y\}^{\prime}$

A possible Arabic parallel for the first name, which does not occur anywhere else, is Udad. The scond name is known neither in Nabataean nor in Arabic. The reading of $g y^{\prime}$ in this text is uncertain but I consider that the letter after $g$ is a badly formed $y$ and that the vertical stroke which follows is the ligature between this $y$ and the very archaic form of the ?

- ThMNN 539 (UJadhNab 350)

Nabataean, Umm Jadhāyidh. Also published in Nehmé 2018.

[Insert here Nehme_fig18_UJadh_350 and the following caption: Photo and facsimile L. Nehmé]

šlm $q s^{`} d r$ br $\{b n\} h b l$

$w d k y r b t b$

This text is interesting because it contains both a theophoric name built with the name of the Edomite deity Qōs and a theophoric name built with Hubal, of which this is the third attestation in Nabataean and the second with the Arabic compound $b n$ rather than Aramaic $b r$ for "son of". It is bnhbl in Puteoli (CIS II 158) and Umm Jadhāyidh and brhbl in Petra (Milik and Starcky 1975: no. 5, p. 120-122). 


\section{- ThMNN 602 (UJadhNab 105)}

Nabataeo-Arabic, Umm Jadhāyidh. Also published in Nehmé 2018.

[Insert here Nehme_fig19_UJadh 105 and the following caption: Photo and facsimile L. Nehmé]

Nehmé 2010: 75-76, fig. 37.

$d k y r \check{s}^{c} d w$

$b r{ }^{`} b d^{\prime} y \check{s}$

bšlm

"May Sa'dū son of 'Abd'īs/'Abd'iyās be remembered in well-being”.

- ThMNN 701 (UJadhNab 145)

Nabataean, Umm Jadhāyidh. Also published in Nehmé 2018.

[Insert here Nehme_fig20_UJadh145_from_Theeb_226 and the following caption: Photo S. alTheeb and facsimile L. Nehmé]

šlm ‘bdṣlm

"May 'Abdșalm be safe".

- ThMNN 862

(Early) Nabataeo-Arabic, Tabūk region. Also published in Nehmé 2018.

To my knowledge, no photograph of this text is available.

[Insert here Nehme_fig21_ThMNN_862_fs_Theeb_2010 and the following caption: Facsimile S. al-Theeb]

dkyr \{t\}ymw w šlmn bny

$\check{s} y^{(?)} l h y$

"May $\{$ T $\}$ aymū and Salmān the sons of Šay"allāhī be remembered".

This text is presented here because it contains to my knowledge the only example of the presence of the compound -lhy in a text written in Nabataeo-Arabic characters. Compare with the Arabic name Šay'allāt.

- TS14NabAr1

Nabataeo-Arabic, al-Șulaylāt, Taymā' region. Previously unpublished. I am grateful to Michael Macdonald for letting me present it here.

[Insert here Nehme_fig22_TS014NabAr1_TS2013a0491B and the following caption: Photo M.C.A. MAcdonald]

$d k y r y w\{z / n\} w b r{ }^{\prime} b d^{\prime} l l^{c} z$ '

"May Y $\bar{u}\{z / n\} \bar{u}$ son of 'Abd'al'uzzā be remembered".

The first name is not previously attested in Nabataean. It is just possible to read $y w l w$, which occurs once in ThNJUT 51, but one would expect the $l$ to be slightly higher than the other letters, as is the $l$ in ' $b d^{\prime} l{ }^{c} z$ '.

- UJadhNab 72

Mixed Nabataean and Nabataeo-Arabic, Umm Jadhāyidh. Published in Nehmé 2018. 
[Insert here Nehme_fig23_UJadh72.jpg and the following caption: Photo and facsimile L. Nehmé]

$<d>d k y r$ 'bd'lšm’ br rbw btb

"May 'Abd'lšamā son of Rabū be remembered in well-being".

Note that $b t b$ is not visible on the photograph. This text is presented here because it contains the only theophoric name built with $\check{s} m^{\prime}$ known so far and because it offers an interesting parallel to the god $\check{s} m y^{\prime}$ mentioned in two texts from Madā' in Ṣāliḥ presented above (64114_I04 and ThMNN 166).

\section{- UJadhNab 313}

Nabataeo-Arabic, Umm Jadhāyidh. Published in Nehmé 2018.

This text, as well as UJadhNab 345, 364 and 368 have already been mentioned in other contributions because the four of them contain a formula which is not attested elsewhere, neither in the Nabataean nor in the Nabataeo-Arabic epigraphic corpus (Nehmé 2017a: 82-83 and Nehmé 2017b: 128-129). This formula is based on the use of the verb ŠMc ${ }^{c}$ in the 3rd person singular of the perfect with an optative force, followed by the divine name al- 'Uzza- There is an exact parallel with the radical DKR in the formula $d k r$ 'l'lh, "May God remember" which occurs in DaJ144PAr1 and DaJ000NabAr1 presented above.

[Insert here Nehme_fig24_UJadh 313 and the following caption: Photo and facsimile L. Nehmé]

šm't

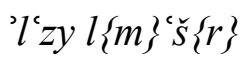

' $\{z / r\} m k t b$

"May al-'Uzzay listen to $\{\mathrm{M}\} \mathrm{a}$ ‘ ša $\{\mathrm{r}\}$. 'A $\{\mathrm{z} / \mathrm{r}\} \mathrm{m}$ wrote”.

$M \check{s} r$ may be the Arabic name Ma`šar but note that the first letter could be also be read as a $q$ or a $p$. As for the name in the third line, it is probably best read ' $z m$ because the shape of the second letter is very similar to that of the $z$ in al- ${ }^{-}$Uzzā. Besides, the name ' $z m w$ occurs in a Tayma $\vec{a}$ Aramaic inscription, CIS II 336, this time with a final $w$. If it is indeed the same name, it is interesting to have it once with wawation in Taymā' Aramaic and without wawation in Nabataeo-Arabic. The same name appears also in UJadhNab 364, for which see below. Note that the goddess' name is spelled with a final $y$, which suggests that her name was pronounced 'uzzay, not 'uzzā.

\section{- UJadhNab 331}

Nabataeo-Arabic, Umm Jadhāyidh. Published in Nehmé 2018.

[Insert here Nehme_fig25_UJadh 331 and the following caption: Photo and facsimile L. Nehmé]

' $b d$ 'lt

$b r{ }^{3} w \check{s}^{\prime} w \check{s} l m$

"May 'Abd'allāt son of 'Awšū be safe".

The name 'Abd'allāt is not attested in Nabataean. It is the feminine equivalent of Arabic 'Abdallāh, the closest parallels of which in Arabic are Awsallāt, Nahdallāt, Sa'dallāt, Wahballāt, Zaydallāt, etc. 


\section{- UJadhNab 345}

[Insert here Nehme_fig26_UJadh345 and the following caption: Photo and facsimile L. Nehmé]

Nabataeo-Arabic, Umm Jadhāyidh. Published in Nehmé 2018.

$\check{s} m^{\prime} t$

$l\left\{\left\{^{c}\right\} d\{y / n\} w\right.$

br $\{s, b\} r h$

'l'zy

"May al-'Uzzay listen to 'Adyū/'Udayyū/'Addānū son of Șabira/Ṣabra/Șubāra”.

The syntax is odd since one would normally expect al- 'Uzzā to follow immediately the verb šm $t$.

- UJadhNab 352

Nabataeo-Arabic, Umm Jadhāyidh. Published in Nehmé 2018.

[Insert here Nehme_fig27_UJadh352 and the following caption: Photo and facsimile L. Nehmé]

dkyr $\{l\}\}^{'} b d^{\prime} l^{c}[z] y$

br $\{\tilde{s}\} l d l l h$

"May 'Abd'al'uzzay son of Šldllh be remembered".

Note the dot above the $d$ of ' $b d^{\prime} l^{c}[z] y$. The reading of the second name is not absolutely certain because one may read $y h$ at the beginning, but a close examination of the photograph shows that the small protrusion which appears in grey on the facsimile is a break and does not belong to the letter. The double $l$ before the final $h$ seems clear. It is possible that this is the equivalent of the name šld'lhy found in QNNab 5, for which see above. One has probably to assume a name *šld'l'lh where both ' are assimilated.

\section{- UJadhNab 364}

Nabataeo-Arabic, Umm Jadhāyidh. Published in Nehmé 2018.

[Insert here Nehme_fig28_UJadh364 and the following caption: Photo and facsimile L. Nehmé]

šm ${ }^{\mathrm{t}} t$

' $l ' z y$

$l^{\prime}\{z / r\} m$

"May al-'Uzzay listen to 'A $\{\mathrm{z} / \mathrm{r}\} \mathrm{m}$ ".

See the commentary under $U J a d h N a b 313 .{ }^{\prime} \mathrm{A}\{\mathrm{z} / \mathrm{r}\} \mathrm{m}$ is probably the same individual as the one who wrote UJadhNab 313.

- UJadhNab 368-369

Nabataeo-Arabic, Umm Jadhāyidh. Published in Nehmé 2018.

[Insert here Nehme_fig29_UJadh 368-369 and the following caption: Photo and facsimile L. Nehmé]

šm 't ' l' $z y$

$h\{b / n\} y\{b / n\} w b r ' w s ̌ w$ 
"May al-'Uzzay listen to $\mathrm{H}\{\mathrm{b} / \mathrm{n}\} \mathrm{y}\{\mathrm{b} / \mathrm{n}\} \mathrm{w}$ son of 'Awsū”.

The name may be Arabic Ḥunayn, Habīb, Hubayb, Hubayyib or even Hubayb.

- UJadhNab 399

Nabataean, Umm Jadhāyidh. Published in Nehmé 2018.

[Insert here Nehme_fig30_UJadh 399 and the following caption: Photo and facsimile L. Nehmé]

dkyr bṭb bšlm hn'lt

The reading is certain. $h n^{\prime} l t$ is not attested elsewhere in Nabataean.

- UJadhNab 538

Nabataeo-Arabic, Umm Jadhāyidh. Published in Nehmé 2018.

[Insert here Nehme_fig31_Ujadh_538 and the following caption: Photo Farīq aṣ-Șaḥrā' 2017] bly dkyr šly br 'wšw

$b t b$ šslm mn qdm

$m r y$ ' $7 m^{\prime} w k t b^{\prime} d n h$

ktb ywm ḩg

'l-ptyr šnt m't

$w t \check{s}^{c} y n w \check{s} b^{c}$

"1 Yea! May Šullay son of 'Awšŭ ${ }^{2}$ be remembered in well-being and may he be safe in the presence of ${ }^{3}$ the Lord of world, and this writing ${ }^{4}$ he wrote the day of the feast of the unleavened bread, year one hundred ${ }^{6}$ and ninety-seven [AD 302-303]".

This very interesting AD 303 text was discovered in the area of Umm Jadhāyidh by the Saudi Arabian team of amateur explorers known as Farīq aṣ-Șaḥrā' (www.alsahra.org). The author, Šllay son of 'Awšū, wrote another text in the same area, UJadhNab 309, seven years earlier. The expression ywm hg 'l-ptyr refers to Passover, of which this is the first mention in Northwest Arabia. This text is a good additional argument to interpret $m r y$ ' $/ \mathrm{m}^{\text {' }}$ as the God of the Jews (Robin 2014: 58). For a full commentary, see Nehmé 2018: 186.

- WRPAr3

Pre-Islamic Arabic, Wadi Ramm. Previously unpublished.

[Insert here Nehme_fig32_WRPAr3 and the following caption: Photo G. King]

This text was photographed by Geraldine King in Wadi Ramm and was kindly given to me, with permission to include it in this list, by Michael Macdonald.

'l\{...\}w\{qy\}šs cbdmnpw

The last name is the well-known Arabic name 'Abdmanāf. Note that 'mtmnpw appears in the AD 512 pre-Islamic Zebed inscription (see Macdonald in Fiema et al. 2015: 411).

\section{Concordance of references}

In bold, the reference under which it is quoted in the text. Followed by a \#, texts which are presented in the appendix. For the sigla, see the bibliography.

\begin{tabular}{|l|l|l|l|l|l|l|}
\hline ThMNN & JSNab & CIS II & ThNUJ & UJadhNab & Other reference(s) & Comment \\
\hline ThMNN 1 & JSNab 39 & & & & Nehmé 2009: 43-44 & Published \\
\hline
\end{tabular}




\begin{tabular}{|c|c|c|c|c|c|c|}
\hline ThMNN 9 & JSNab 48 & & & & & Published \\
\hline ThMNN 13 & & CIS II 274 & & & ARNA.Nab 53 & Published \\
\hline ThMNN 14 & JSNab 52 & CIS II 275 & & & & Published \\
\hline ThMNN 19 & JSNab 58 & & & & & Published \\
\hline ThMNN 20 & JSNab 59 & & & & & Published \\
\hline ThMNN 21 & JSNab 57 & CIS II 235 & & & & Published \\
\hline ThMNN 23 & JSNab 61 & CIS II 238 & & & & Published \\
\hline ThMNN 54 & JSNab 92 & & & & ARNA.Nab 71 & Published \\
\hline ThMNN 55\# & JSNab 93 & CIS II 283 & & & ARNA.Nab 72 & $\begin{array}{l}\text { Published, } \\
\text { see appendix }\end{array}$ \\
\hline ThMNN 107\# & JSNab 142 & & & & & $\begin{array}{l}\text { Published, } \\
\text { see appendix }\end{array}$ \\
\hline ThMNN 108 & JSNab 143 & & & & & Published \\
\hline ThMNN 113 & JSNab 149 & & & & & Published \\
\hline ThMNN 127 & JSNab 163 & CIS II 244 & & & & Published \\
\hline ThMNN 128 & JSNab 164 & CIS II 244 & & & & Published \\
\hline ThMNN 133 & JSNab 169 & & & & & Published \\
\hline ThMNN 166\# & & CIS II 236 & & & & $\begin{array}{l}\text { Published, } \\
\text { see appendix }\end{array}$ \\
\hline ThMNN 190 & JSNab 1 & CIS II 199 & & & & Published \\
\hline ThMNN 197 & JSNab 8 & CIS II 197 & & & & Published \\
\hline ThMNN 200 & JSNab 11 & CIS II 211 & & & & Published \\
\hline ThMNN 201 & JSNab 12 & CIS II 205 & & & & Published \\
\hline ThMNN 205 & JSNab 16 & CIS II 198 & & & & Published \\
\hline ThMNN 206 & JSNab 17 & CIS II 271 & & & & Published \\
\hline ThMNN 209 & JSNab 19 & CIS II 206 & & & & Published \\
\hline ThMNN 218 & JSNab 28 & CIS II 208 & & & & Published \\
\hline ThMNN 220 & JSNab 30 & CIS II 200 & & & & Published \\
\hline ThMNN 221 & JSNab 31 & CIS II 217 & & & & Published \\
\hline ThMNN 224 & JSNab 34 & CIS II 224 & & & & Published \\
\hline ThMNN 226 & JSNab 36 & CIS II 209 & & & & Published \\
\hline ThMNN 278 & JSNab 184 & $C I S$ II 320F & & & & Published \\
\hline ThMNN 292 & JSNab 198 & & & & & Published \\
\hline ThMNN 295 & JSNab 201 & & & & & Published \\
\hline ThMNN 306 & JSNab 212 & & & & & Published \\
\hline ThMNN 307 & $\begin{array}{l}\text { JSNab } \\
213+214\end{array}$ & & & & & Published \\
\hline ThMNN 327 & JSNab 234 & & & & & Published \\
\hline ThMNN 440 & JSNab 385 & & & & & Published \\
\hline ThMNN 448 & & & & & ARNA.Nab 24 & Published \\
\hline ThMNN 449 & & & & & ARNA.Nab 25 & Published \\
\hline ThMNN 477\# & & & ThNUJ 7 & UJadhNab 88 & & $\begin{array}{l}\text { Published, } \\
\text { see appendix }\end{array}$ \\
\hline ThMNN 488 & & & ThNUJ 18 & UJadhNab 83 & & Published \\
\hline ThMNN 497 & & & ThNUJ 25 & UJadhNab 97 & & Published \\
\hline ThMNN 539\# & & & ThNUJ 68 & UJadhNab 350 & & $\begin{array}{l}\text { Published, } \\
\text { see appendix }\end{array}$ \\
\hline ThMNN 549 & & & ThNUJ 77 & UJadhNab 295 & & Published \\
\hline ThMNN 555 & & & ThNUJ 83 & UJadhNab 228 & & Published \\
\hline ThMNN 556 & & & ThNUJ 84 & UJadhNab 219 & Nehmé 2010: 77-78 & Published \\
\hline ThMNN 583 & & & ThNUJ 111 & UJadhNab 137 & & Published \\
\hline ThMNN 584 & & & ThNUJ 112 & UJadhNab 134 & & Published \\
\hline ThMNN 585 & & & ThNUJ 113 & UJadhNab 133 & & Published \\
\hline ThMNN 595 & & & ThNUJ 121 & UJadhNab 117 & & Published \\
\hline ThMNN 602\# & & & ThNUJ 128 & UJadhNab 105 & Nehmé 2010: 75-76 & $\begin{array}{l}\text { Published, } \\
\text { see appendix }\end{array}$ \\
\hline ThMNN 644 & & & ThNUJ 170 & UJadhNab 445 & & Published \\
\hline ThMNN 662 & & & ThNUJ 188 & UJadhNab 237 & & Published \\
\hline ThMNN 678 & & & ThNUJ 204 & UJadhNab 186 & & Published \\
\hline ThMNN 681 & & & ThNUJ 207 & UJadhNab 189 & & Published \\
\hline ThMNN 688 & & & ThNUJ 213 & UJadhNab 41 & & Published \\
\hline ThMNN 692 & & & ThNUJ 217 & UJadhNab 47 & & Published \\
\hline ThMNN 695 & & & ThNUJ 220 & UJadhNab 426 & & Published \\
\hline
\end{tabular}




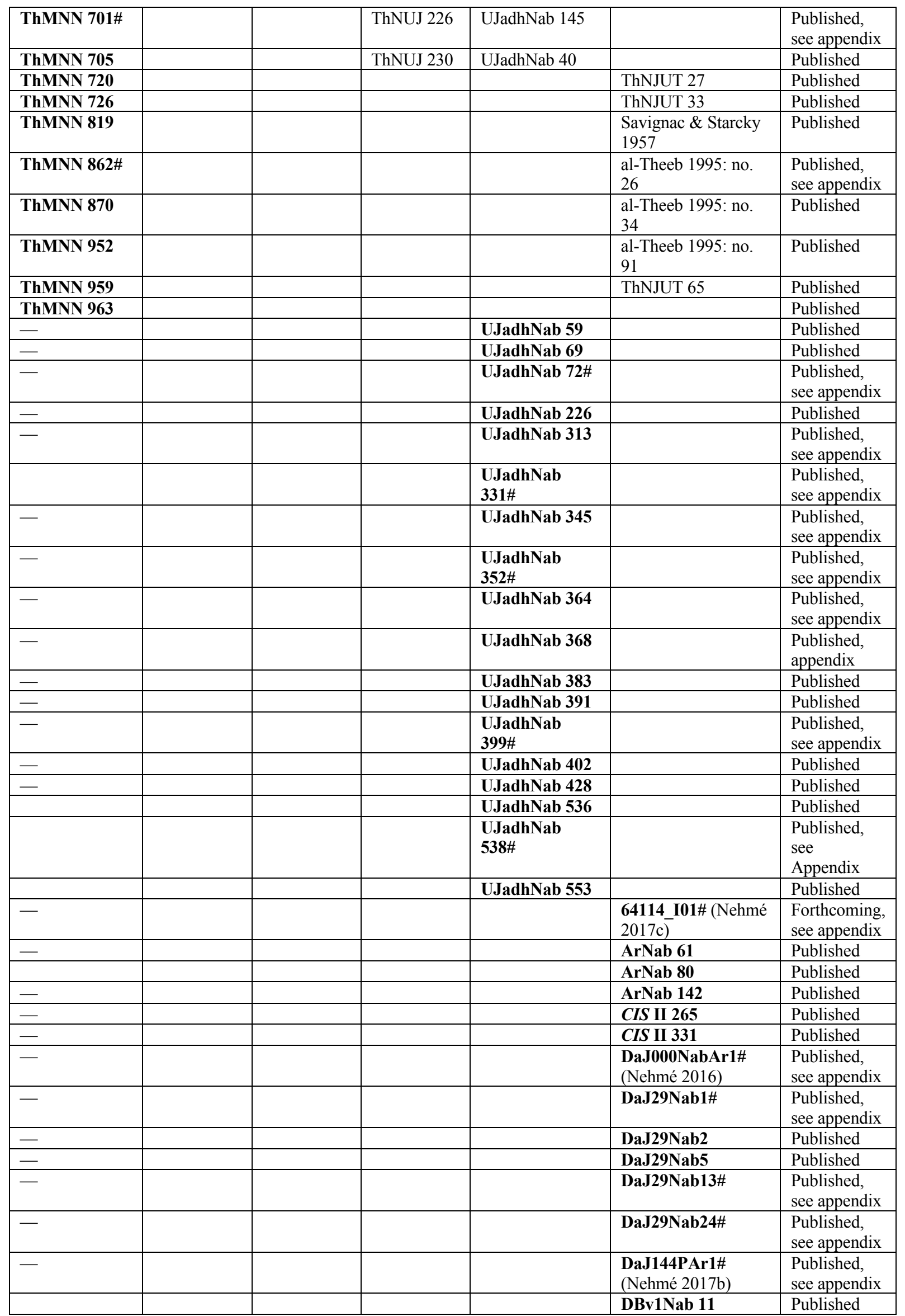




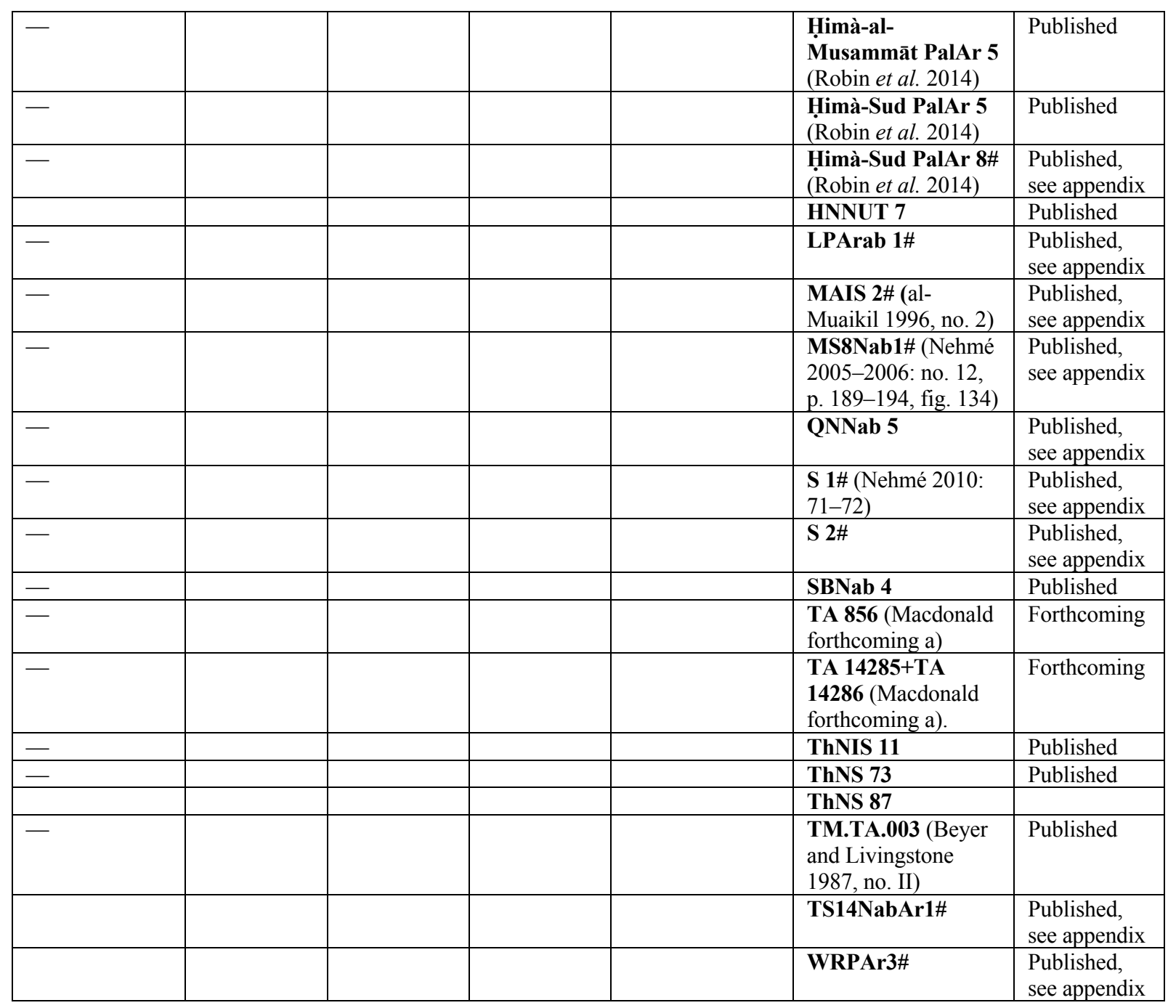

\section{Bibliography}

Sigla

ArNab. Inscriptions from al-'Arniyyāt published in NeHMÉ 2018.

ARNA.Nab. WINNETT \& REED 1970.

CIS. Corpus Inscriptionum Semiticarum. Pars II. Inscriptiones Aramaicas continens. Paris, 1889-.

DaJ. Inscriptions from Dūmat al-Jandal.

DBv1Nab and DBv3Nab. Inscriptions from sites Darb al-Bakrah various 1 and various 3 published in NEHMÉ 2018.

HNNUT. al-Hầ iṭ̂̄ 2016.

JSNab. JAUSSEN \& SAVIGNAC 1909-1922.

LPArab. LITTMANN 1949

MAIS. AL-MUAIKIL 1993.

MS. Inscriptions from Madā’ in Șāliḥ.

QNNab. Inscriptions from Q⿱āc an-Naqayb published in NEHMÉ 2018. 
RES. Répertoire d'épigraphie sémitique. Paris, 1900-1968.

S. Inscriptions from Sakākā.

SBNab. Inscriptions from Sūḥ al-Baghlah published in NEHMÉ 2018.

ThMNN. AL-THEEB 2010.

ThNIS. AL-THEEB $2011 \mathrm{~b}$.

ThNJUT. AL-THEEB 2005.

ThNS. AL-THEEB 2014.

TS. Inscriptions from the Taymā' Survey.

UJadhNab. Inscriptions from Umm Jadhāyidh published in NEHMÉ 2018.

\section{References}

AL-JALLAD A.

2015 An Outline of the Grammar of the Safaitic Inscriptions. Studies in Semitic Languages and Linguistics 80. Leiden \& Boston: Brill.

AlPASS P.

2013 The Religious Life of Nabataea (Religons in the Graeco-Roman World 175). Leiden \& Boston: Brill.

BEYER K. \& LiVINGSTONE A.

1987 "Die neuesten aramäischen Inschriften aus Taima", Zeitschrift der deutschen morgenländischen Gesellschaft 137, p. 285-296.

Charloux G., Al-TraAd, A.K., Al-QAeEd A., and Morel Q.

2016 "The Western Settlement. Sector C", in Dûma 2. The 2011 Report of the SaudiItalian-French Archaeological Project at Dûmat al-Jandal, Saudi Arabia, edited by G. Charloux \& R. LORETo (A Series of Archaeological Refereed Studies 41). Riyadh: SCTH, p. 187-229.

COWLEY A.

1923 Aramaic Papyri of the Fifth Century B.C. Oxford: Clarendon Press.

DALMAN G.

1912 Neue Petra-Forschungen und der heilige Felsen von Jerusalem. Leipzig: J.C. Hinrichs.

Doughty C.

1884 Documents épigraphiques recueillis dans le nord de l'Arabie par M. Charles Doughty. Paris: Imprimerie Nationale.

ESKOUBI Kh.M.

1999 Dirāsah taḥlīliyyah muqāranah li-nuqūs min mințaqah (rum) janūb ġarb taymā'. Al-riyāḍ: wikālat al-'ātār wa-l-matāhif.

2007. Dirāsah tahlīliyyah muqāranah li-nuqūš țamūdiyyah min mințaqat rum bayna țalītawāt

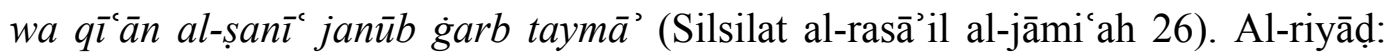
Dārat al-malik 'abd al-'azīz.

FiEMA Z.T., Al-JALlad A., MACDONALD M.C.A., and NeHMÉ L. 
"Provincia Arabia: Nabataea, the Emergence of Arabic as a Written Language, and Graeco-Arabica", in Arabs and Empires Before Islam, edited by G. Fisher. Oxford: Oxford University Press, p. 373-433.

AL-GHABBĀN 'A.

2007 "Le Darb al-Bakra. Découverte d'une nouvelle branche sur la route commerciale antique, entre al-Hijr (Arabie Sa ūdite) et Pétra (Jordanie)", Comptes rendus de l'Académie des Inscriptions \& Belles-Lettres, p. 9-24.

2008 "The Inscription of Zuhayr, the Oldest Islamic Inscription (24 AH/AD 644-645), the Rise of the Arabic Script and the Nature of the Early Islamic State", Arabian Archaeology and Epigraphy 19, p. 209-236.

AL-Ḥ̂̀̄IṬī Kh.

2016 Al-nuqūš al-nabatiyyah fì al-manātiq al-wāqi '`ah bayna muhāfazatay al- 'ulā wa tayma $\bar{a}^{\prime}$ (Silsilat dirāsāt 'atariyyah muhakkamah 35). Al-riyāḍ: SCTH.

HEALEY J.

1993 The Nabataean Tomb Inscriptions of Mada'in Salih (Journal of Semitic Studies Supplement 1). Oxford: Oxford University Press.

JASTROW M.

1903 A Dictionary of the Targumim, the Talmud Babli and Yerushalmi, and the Midrashic Literature. London: Luzac \& Co. and New York: G.P. Putnam's sons.

JAUSSEN A. \& SAVIGNAC R.

1909-1922 Mission archéologique en Arabie (Publications de la Société Française des Fouilles Archéologiques 2). Paris: Geuthner (5 volumes).

LANE E.W.

1863-1893 An Arabic-English Lexicon. Derived from the Best and Most Copious Eastern Sources. London: Williams \& Norgate.

LITTMANN E.

1949 Arabic Inscriptions. Publications of the Princeton University Archaeological Expedition to Syria in 1904-1905, Division IV, Section D. Leiden: Brill.

Livingstone A., Khan M., Zahrani A., SAlluK M., and Shaman S.

1985 “Epigraphic Survey, 1404-1984”, Atlal 9, p. 128-144, pl. 118-135.

MACDONALD M.C.A.

1999 "Personal Names in the Nabataean Realm. A Review Article", Journal of Semitic Studies 44, p. 251-289.

2010 "Ancient Arabia and the Written Word", in The Development of Arabic as a Written Language, edited by M.C.A. MACDONALD (Supplement to the Proceedings of the Seminar for Arabian Studies 40). Oxford: Archaeopress, p. 5-28.

Forthcoming a. Taym $\vec{a}$ Aramaic, Nabataean, and Taymanitic Inscriptions from the SaudiGerman Excavations at Taymä.

MACDONALD M.C.A. \& AL-NAJEM M. (with contributions by F. IMBERT and P. STEIN). 
Forthcoming Catalogue of the Inscriptions in the Taymä Museum.

MiLIK J.T.

1958 "Nouvelles inscriptions nabatéennes", Syria 35, p. 227-251, pl. 18-21.

1972 Dédicaces faites par des dieux (Palmyre, Hatra, Tyr) et des thiases sémitiques à l'époque romaine (Bibliothèque archéologique et historique 92; Recherches d'épigraphie proche-orientale 1). Paris: Geuthner.

MiLIK J.T. \& STARCKY J.

1975 "Inscriptions récemment découvertes à Pétra", Annual of the Department of Antiquities of Jordan 20, p. 111-130, pl. 37-47.

MORITZ B.

1908 "Ausflüge in der Arabia Petrăa”, Mélanges de la Faculté orientale 3, p. 387-436, pl. $1-7$.

AL-MUAIKIL Kh.

1993 "Naqšān ‘arabiyyān mubakkirān min sakāka”, Addarah 19.3, p. 112-131.

NEBES N.

2009 “Die Nabatäer in Südarabien”, Antike Welt 40.1, p. 52-53.

NEGEV A.

1963 "Nabatean Inscriptions from 'Avdat (Oboda)", Israel Exploration Journal 13, p. 113-124, pl. 17-18.

1991 Personal Names in the Nabataean Realm (Qedem 32). Jerusalem: The Hebrew University.

NEHME L.

1997 “L'espace cultuel de Pétra à l'époque nabatéenne”, Topoi 7, p. 1023-1067.

2005-2006 “Inscriptions vues et revues à Madā’in Șāliḥ”, Arabia 3, p. 179-225 [text], 345356 [figs].

2009 "Quelques éléments de réflexion sur Hégra et sa région à partir du II siècle après J.-C.”, in L'Arabie à la veille de l'Islam. Bilan clinique, edited by J. Schiettecatte \& Chr.J. Robin (Orient \& Méditerrannée 3). Paris: De Boccard, p. 37-58.

2010 "A Glimpse of the Development of the Nabataean Script into Arabic Based on Old and New Epigraphic Material", in The Development of Arabic as a Written Language, edited by M.C.A. MACDONALD (Supplement to the Proceedings of the Seminar for Arabian Studies 40). Oxford: Archaeopress, p. 47-88.

2012a Atlas archéologique et épigraphique de Pétra. Fascicule 1. De Bāb as-Sīq au Wādī al-Farasah (Épigraphie \& Archéologie 1). Paris: Académie des Inscriptions et Belles-Lettres.

2012 b "A Recently-Discovered Nabataean Sanctuary, Possibly Devoted to the Sun-God", in From Ugarit to Nabataea. Studies in Honor of John F. Healey, edited by 
G.A. KiRAZ and Z. AL-SAlameEn (Gorgias Ugaritic Studies 6). Piscataway (NJ): Gorgias Press, p. 153-166, pl. 1-5 on pages 266-270.

2013 "The installation of social groups in Petra", in Men on the Rocks. The Formation of Nabataean Petra, edited by M. MouTON and S.G. SCHMID. Berlin: logos, p. 113127.

2016 “A 'Transitional' Inscription from Dûmat al-Jandal”, in Dûma 2. The 2011 Report of the Saudi-Italian-French Archaeological Project at Dûmat al-Jandal, Saudi Arabia, edited by G. CHARLOUX \& R. LORETO (A Series of Archaeological Refereed Studies 41). Riyadh: SCTH, p. 231-233.

2017a "Aramaic or Arabic? The Nabataeo-Arabic Script and the Language of the Inscriptions Written in this Script", in Arabic in Context. Celebrating 400 years of Arabic at Leiden University, edited by A. AL-JALLAD (Studies in Semitic Languages and Linguistics 89). Leiden: Brill, p. 75-98.

2017b "New Dated Inscriptions (Nabataean and pre-Islamic Arabic) from a Site Near alJawf, ancient Dūmah, Saudi Arabia", Arabian Epigraphic Notes, p. 121-164.

2017c “A New Nabataean Inscription Mentioning "[the God of] Heaven", in Report on the 2017 Season of the Madâ 'in Sâlih Archaeological Project, edited by L. NEHMÉ, forthcoming. Online at: https://hal.archives-ouvertes.fr/hal-01804965 [accessed March 2020].

OCIANA database online. http://krcfm.orient.ox.ac.uk/fmi/webd/ociana [accessed March 2020].

2018 (ed.) The Darb al-Bakrah. A Caravan Route in North-West Arabia Discovered by Ali I. al-Ghabban. Catalogue of the inscriptions. Riyadh: Saudi Commmission for Tourism and National Heritage (A Series of Archaeological Refereed Studies, 50). Online at: https://hal.archives-ouvertes.fr/hal-02096586v1 [accessed March 2020].

ROBIN C.J.

2008 "Les Arabes de Himyar, des "Romains" et des Perses (III"-VI ${ }^{\mathrm{e}}$ siècles de l'ère chrétienne)", Semitica et Classica 1, p. 167-202.

2013 "Les religions pratiquées par les membres de la tribu de Kinda (Arabie) à la veille de l'Islam", Judaïsme Ancien - Ancient Judaism 1, p. 203-261.

2014 "The Peoples Beyond the Arabian Frontier in Late Antiquity: Recent Epigraphic Discoveries and Latest Advances », in Inside and Out. Interactions Between Rome and the Peoples on the Arabian and Egyptian Frontiers in Late Antiquity, edited by DiJKsTRA J.H.F. \& Fisher G. Leuven, Paris, Walpole: Peeters, p. 33-79.

2015 “Quel judaïsme en Arabie?”, in Le judaïsme de l'Arabie antique (Judaïsme ancien et origines du christianisme 3), edited by C.J. RoBIN. Turnhout: Brepols, p. 15-295.

RoBIN C., AL-GHABBĀN 'A.I., and AL-SA'ĪD S.F.

2014 "Inscriptions antiques de la région de Najrān (Arabie Séoudite méridionale): nouveaux jalons pour l'histoire de l'écriture, de la langue et du calendrier arabes", Comptes rendus de l'Académie des Inscriptions \& Belles-Lettres, p. 1033-1128. 
AL-SALAMEEN Z. \& Shdaifat Y.

2017 "A New Nabataean Inscription from the Moab Plateau", Arabian Epigraphic Notes 3: $1-10$.

SAVIGNAC R.

1933 “Le sanctuaire d'Allat à Iram (1)”, Revue biblique 42, p. 405-422, pl. 24.

1934 "Le sanctuaire d'Allat à Iram (suite)", Revue biblique 43, p. 572-591, pl. 35-39.

SAVIGNAC R. \& STARCKY J.

1957 "Une inscription nabatéenne provenant du Djôf", Revue biblique 64, p. 196-217, pl. 5 .

AL-ShDAifAT Y., Al-Jallad A., AL-SAlAMEEn Z., HARAHSHEH R.

2017 "An Early Christian Arabic Graffito Mentioning 'Yazīd the king", Arabian Archaeology and Epigraphy 28, p. 315-324.

SOKOLOFF M.

2009 A Syriac Lexicon. A Translation from the Latin, Corrrection, Expansion, and Update of C. Brockelmann's Lexicon Syriacum. Winona Lake (IN)-Piscataway (NJ): Eisenbrauns-Gorgias Press.

\section{STARCKY J.}

1954 "Un contrat nabatéen sur papyrus”, Revue biblique 61, p. 161-181, pl. 1-3.

STRUGNELL J.

1959 "The Nabataean Goddess Al-Kutba' and her Sanctuaries", Bulletin of the American Schools of Oriental Research 156, p. 29-36.

AL-THEEB S.

1995 Dirāsah taḥlīliyyah li-nuqūš nabațiyyah qadīmah min šamāl ġarb al-mamlakah al'arabiyyah al-sa'ūdiyyah. Al-riyāḍ: Maṭū'āt maktabat al-malik fahd alwațaniyyah.

2005 Nuqūš nabațiyyah fì al-jawf, al-'ulā, taymā', al-mamlakah al-'arabiyyah alsu'ūdiyyah. Al-riyāḍ: Maṭb̄̄āt maktabat al-malik fahd al-wațaniyyah.

2010 Mudawwanat al-nuqūš al-nabațiyyah fì 'l-mamlakah al- 'arabiyyah al-sa 'üdiyyah. Al-riyāụ: Dārat al-malik 'abdul' azīz.

2011a "Nuqūš nabaṭiyyah jad̄̄dah min mawqi` huḍaybāt al-maḍla‘ān̄̄”, Addarah 27, p. $47-67$.

$2011 b$ "New Nabataean inscriptions from the site of al-Sīj in the region of al-'Ulā, Saudi Arabia", Proceedings of the Seminar for Arabian Studies 41, p. 349-370.

2014 Nuqūš mawqi sarmadā’ muhāafazat taymā’ . Al-riyāḍ: Jāmi'at al-malik sa ūd, kulliyyat as-siyāḥah wa-1-'ātāir.

VAN PUTTEN M.

2017 "The development of the triphtongs in Quranic and Classical Arabic", Arabian Epigraphic Notes 3, p. 47-74.

WINNETT F.V. \& REED W.L. 
1970 Ancient Records from North Arabia. Toronto: University of Toronto Press.

YARDENI A.

2001 "The Decipherment and Restoration of Legal Texts from the Judaean Desert: A Reexamination of Papyrus Starcky (P. Yadin 36)", Scripta Classica Israelitica 20, p. 121-137.

2014 "A List of the Arabic Words Appearing in Nabataean and Aramaic Legal Documents from the Judaean Desert”, Scripta Classica Israelica 33, p. 301-324. 